\title{
The Role of Horticulture in the Prehistoric Apishapa Region of Southeastern Colorado
}

\author{
Christian J. Zier \\ Editor, Southwestern Lore
}

\begin{abstract}
At least 40 sites in the Apishapa region of southeastern Colorado and adjacent portions of New Mexico and Oklahoma have produced evidence of prehistoric maize. Firmly dated remains range in age from Late Archaic through Late Prehistoric, with the greatest occurrence between A.D. 550 and 1350. Maize was widespread throughout the region but the remains at individual sites are typically scant. The occurrence of maize increases in frequency over time, a trend that correlates more readily with population increase than climatic variation. The long-standing hunter-gatherer economy of southeastern Colorado persisted into Late Prehistoric times and was supplemented but not replaced by maize horticulture. Over time, pressure on resources resulted in a reduction in mobility and corresponding coalescence of populations into seasonally-occupied sites in canyon areas where resource diversity and availability were greatest. Prolonged drought after A.D. 1000 resulted in abandonment of southeastern Colorado ca. A.D. 1450. A mixed hunter-gatherer and horticultural economy characterized this period, although procurement of wild plant foods and hunting (mostly small mammals) remained prevalent. The failure of maize horticulture to assume a more prominent role in Apishapa subsistence practices may reflect the marginal nature of the semi-arid environment, where even today the growing of food crops is limited both by availability of water and, in some areas, elevation.
\end{abstract}

Keywords: Apishapa phase; horticulture; maize; mixed economy; population growth

Archaeologists have long noted the presence of agricultural products, especially maize (corn), in widely distributed prehistoric sites in southeastern Colorado. In the most recent prehistoric context document for the Arkansas River basin of Colorado, Zier and Kalasz (1999:138-140, 176-178, 246) pose a series of questions regarding agriculture during the Late Archaic period and the two subsequent periods of the Late Prehistoric stage, namely the Developmental and Diversification periods. These questions revolve around the timing of the first appearance of maize in the region; the possible association between the appearance of maize and evident population increase during the Late Archaic period; the nature of economic adjustments that attended the introduction of maize to the existing hunter-gatherer subsistence base; the degree to which cultivation of beans occurred within the context area; and the distribution of maize both geographically and temporally within the context area. To these questions an overriding query may be added: Why did the transition from full-time hunter-gathers to part-time horticulturalists happen at all?

The archaeological database for prehistoric maize and other agricultural products in the region has expanded only incrementally, not dramatically, since the publication of the 1999 context document, as the citations in table 1 suggest. Regardless, the subject of the beginnings of food production merits 
a fresh look. Better supported and much more finely calibrated paleoclimatic information is available for the past three millennia in the western High Plains, and human population growth trends are better understood, facilitating a reexamination of the relationships among climatic change, population, and food production. The body of literature dealing with in between economies-those employing both foraging for wild foods and production of cultivated foods-has developed greatly in recent years, providing an improved conceptual framework for understanding cultural processes in southeastern Colorado. Consideration is also given to the prehistoric manipulation of locally available wild food plants that may have provided a cultural bridge to the acceptance and production of plants, such as maize, that were domesticated outside the region.

This paper begins with an examination of the archaeological evidence for agriculture within the Apishapa region. This evidence is then regarded in a larger geographical context that includes the Greater Southwest, the region from which food crops in southeastern Colorado are believed to have diffused. Next, the cultural processes that lead to the adoption of food production by huntergatherers are considered. This reconstruction employs southeastern Colorado data to the extent possible but also incorporates information from a far broader area to fill in regional data gaps. Finally, suggestions are proffered for future studies that would best contribute to an enhanced understanding of horticulture-its origins and economic importance, as well as its relationship to cultural and environmental processes-in the Apishapa region.

\section{Definitions and Cultural Systematics}

Kalasz and colleagues (1999:69-72) established the chronological framework in current use in the Arkansas River basin, a sequence that extends back in time approximately 11,500 years. Three major cultural stages (Paleoindian, Archaic, and Late Prehistoric) are subdivided internally into periods of varying duration based on perceptible changes in the archaeological record. Of primary concern here are the Late Archaic period (1050 B.C.-A.D. 100) of the Archaic stage, and the Developmental period (A.D. 100-1050) and Diversification period
(A.D. 1050-1450) of the Late Prehistoric stage. It is these cultural-chronological units with which nearly all dated agricultural evidence in the region is associated.

The Diversification period is further divided into two phases, referred to as Apishapa and Sopris. These phases are essentially contemporaneous although the temporal span of the Sopris phase is much shorter, ca. A.D. 1050-1200. As shown in figure 1, the Apishapa phase lies entirely to the east of the Southern Rocky Mountains and extends geographically from north of the Arkansas River in the Pueblo, Colorado vicinity to extreme northeastern New Mexico and the western tip of the Oklahoma Panhandle. While occupying a position on the western High Plains, the Apishapa phase encompasses an extensive area of canyon lands associated with the Purgatoire River and its tributaries as well as segments of certain entrenched tributaries of the Arkansas River, such as the Apishapa River to the south and Turkey and Beaver creeks to the north. The Sopris phase lies to the west and southwest of the Apishapa phase, its range coinciding geographically with the Park Plateau in the foothills of the southern Sangre de Cristo Mountains.

The terms agriculture and horticulture commonly appear in the literature of prehistoric farmers and they are often used interchangeably. Generally, however, agriculture suggests a focus on one primary domesticated crop while horticulture is more broad-spectrum in nature. With agriculture, there are also implications for greater scale and the use of more sophisticated technology than is the case with horticulture. Neither term meshes perfectly with the subsistence regimen of the prehistoric Apishapa, although horticulture seems a better fit. From the standpoint of domestic plant use, the Apishapa appear to have limited themselves mainly to maize, but still retained an Archaic-like economy that relied heavily on hunting large and small game and gathering a wide array of wild plants.

Binford (1980), in attempting to explain huntergatherer variability, identified a continuum between foragers and collectors. Foragers are characterized by high residential mobility, using base camps established in favorable locations that permit access to key resources as they become available at specific times during the year. Collectors exhibit high 


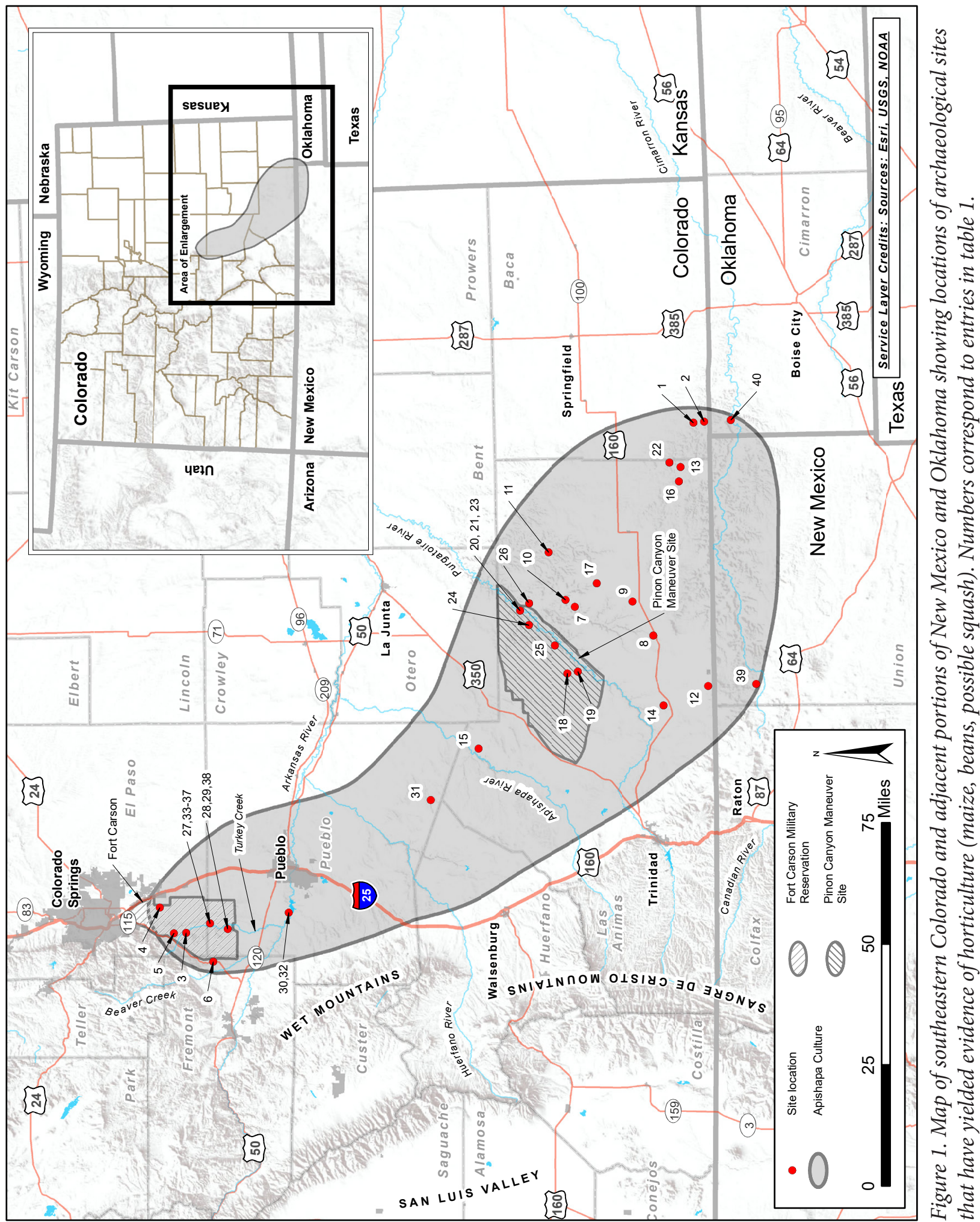


logistical mobility but tend to reside in one or a limited number of central places for longer periods of time than, for example, foragers in base camps, and use specialized task groups to acquire resources that are brought back to the central place (see also Barker 2006; Habu and Fitzhugh 2002). The forager model better describes the prehistoric Apishapa region throughout most of prehistory. However, it should be borne in mind that no prehistoric settlement system can be pigeonholed into one model or the other, and that the two concepts do indeed represent opposite ends of a continuum of mobility strategies (Perreault and Brantingham 2010). Late Archaic and Late Prehistoric population growth, and the reduction of individual group mobility that presumably resulted, contributed to a blurring of the forager-collector distinction over time in southeastern Colorado.

\section{Environmental Context}

The southeastern Colorado landscape defies stereotypical description. The vast area extending from the Sangre de Cristo Mountains to the eastern border of the state comprises portions of the Raton and Colorado Piedmont sections of the Great Plains physiographic province (Thornbury 1965:310315). The Chaquaqua Plateau is an extensive manifestation of the Raton section that lies between the Colorado-New Mexico border and the valley of the Arkansas River, and stretches eastward for over one hundred miles from the foothills of the Sangre de Cristos. The Apishapa culture area overlaps the Chaquaqua Plateau to a great deal, although Apishapa sites are also found to the south and southeast of the plateau in northern New Mexico and the far western Oklahoma panhandle, and to the north of the Arkansas River in the Pueblo-Fort Carson area.

The Chaquaqua Plateau is a northeast-sloping upland ranging in elevation mainly between 4500 and $6000 \mathrm{ft}$ although a unique landmark of the plateau, a basaltic feature known as Mesa de Maya, rises to $6800 \mathrm{ft}$ in eastern Las Animas County. The Chaquaqua Plateau is bisected along a southwest/ northeast axis by the Purgatoire River, a major tributary of the upper Arkansas River. Upland areas of the plateau comprise a combination of rolling plains (steppes), buttes, hills, and flat-topped mesas, interrupted occasionally by hogback ridges formed by intrusive volcanic rocks (Campbell 1969:28-37; Schuldenrein 1985:56). The Purgatoire River and its tributaries have created a vast labyrinth of sandstone canyons that exceed $400 \mathrm{ft}$ in depth in some places. While the recent establishment of the U.S. Army Pinon Canyon Maneuver Site in northeastern Las Animas County has drawn particular attention to that sector of the canyon country, this interlocking network extends over a far greater area to include portions of Bent and Otero counties. The lower Apishapa and Huerfano rivers in western Las Animas, Huerfano, and Pueblo counties also exhibit entrenched canyons, as do portions of Baca County in the extreme southeast of the Apishapa region although the latter lie within the Cimarron River drainage basin and are unconnected hydrologically to the Arkansas basin. In the northwestern corner of the Apishapa region, in the Fort Carson vicinity, drainages issuing from the Rampart Range have carved a separate series of small but steep-sided canyons in portions of Pueblo, Fremont, and El Paso counties that empty into the Arkansas River from the north.

The physiographic variability across the region is enormous, and many of the microenvironments that exist are not reminiscent of settings found elsewhere on the Great Plains. This statement is particularly true of the canyon country. The region falls within a shortgrass prairie biome (Mutel and Emerick 1984) but that single descriptor fails to capture its full floral diversity. Pinyon-juniper woodlands (usually juniper-dominated), often discontinuous and scattered, characterize many upland areas such as hills and mesa tops, including canyon rims. Riparian zones ranging from a few to hundreds of feet wide straddle the floodplains of permanent and ephemeral watercourses. Aspen groves occur in some microenvironments within the canyons, typically watered by springs or seeps and encouraged by northern exposure. The fauna is typical of the High Plains although the addition of canyons and timbered uplands to open steppes allows for higher species diversity than is found in most other areas within the plains (Anderson et al. 2013:12-13; Campbell 1969:49-54; Painter et al. 1999:10-11).

The present climate of southeastern Colorado is semi-arid and continental in character, typified by 
significant seasonal and diurnal variations in both temperature and precipitation. Conditions reflect a combination of variables that include latitude, the movement of major air masses, topography and elevation, and local storm-track patterns (Anderson et al. 2013:12-13; Kalasz et al. 2007:13). In general, the area is one of cold winters, hot summers, and persistent winds. The Chaquaqua Plateau receives between 12 and 16 inches of precipitation annually, mainly in the form of late winter/early spring snowfall and summer thunderstorms. Areas flanking the plateau to the west, south, and north have slightly greater annual totals, while the valley of the Arkansas River on the north is drier (Western Regional Climate Center 2016).

As an integral part of a synthetic study of eastern Colorado environmental and cultural change, Gilmore (2008:202-247) produced a paleoenvironmental reconstruction that spans the last approximately 3,000 years. This scheme combined information varying in geographical scale from hemispheric to regional to local, and incorporated the author's analysis of several pocket fens (small peatlands) in eastern Colorado. In addition to the fens, regional information sources consisted of tree-ring sequences, records of aeolian deposition (sand dunes), and lacustrine deposits. Hemispheric climatic reconstructions were based mainly on analysis of peat bogs in northern Europe but also included data from eastern Canada and the Colorado mountains. Gilmore (2008:247) believes the information in aggregate form to be convincing but does acknowledge the idiosyncratic nature of specific climatic records. In other words, broad trends are recognizable but the various lines of data are rarely fully corroborative.

Gilmore (2008:223-235) divides the last three millennia into six climatic periods, excluding the post-A.D. 1860 era during which climatic trends might be attributable to worldwide industrialization. The earliest climatic period, dating 1000-250 B.C., covers all but the last few centuries of the Late Archaic period and is described as generally dry with episodic drought. There is broad evidence of drought on the western Plains during this time, reflected especially in widespread records of sand dune activation, although the timing of episodes of peak aridity is less certain. As Gilmore's label indicates, the subsequent Terminal Archaic
Drought, ca. 250 B.C.-A.D. 100, coincides with the end of the Archaic stage and is described as a period of severe aridity and warming temperatures, in addition to unusually high variability in temperature and precipitation. Conditions began to improve around A.D. 100 at the temporal boundary between the Archaic and Late Prehistoric stages. An interval of approximately two centuries duration followed, during which time temperatures fell and precipitation increased. In southeastern Colorado, this interval coincides with the opening centuries of the Developmental period.

The Early Ceramic Drought, so designated by Gilmore, followed (A.D. 300-550), enduring until the halfway point of the Developmental period. In contrast with the preceding period of drought, arid climatic conditions during this span were accompanied by lowered temperatures. Drought conditions appear to have intensified over the course of the period, with only limited evidence of internal fluctuations in either temperature or precipitation. The First Millennium Amelioration, A.D. 550975, overlaps the latter half of the Developmental period and was a time of increased precipitation and somewhat elevated temperatures. There is evidence from some quarters of one or more arid episodes within this period, but most climatic proxies are suggestive of general consistency rather than variability. The subsequent Medieval Climatic Anomaly, dated A.D. 975-1450, coincides rather neatly with the Diversification period in southeastern Colorado. This climatic interval is broadly recognized in the northern hemisphere in both North America and Europe, and evidence for increasing aridity and elevated temperatures is generally corroborated by regional data sources. However, Gilmore (2008:231-233) observes that some regional proxies are more ambivalent with respect to drought conditions. Evidence suggests that the onset of drought conditions at the beginning of the period was rather dramatic, but that the latter part of the period is characterized by significant climatic variability in terms of effective moisture and temperature. The Little Ice Age is a prolonged period of reduced temperatures and elevated moisture in both North America and Europe. The Little Ice Age begins ca. A.D. 1450 and outruns the Diversification period and Apishapa occupation of southeastern Colorado, and is not discussed further. 


\section{The Evidence}

Any investigation of prehistoric horticulture in the Apishapa region must incorporate all three legs of the maize-beans-squash triad. However, archaeological evidence for beans and squash in the study area is scant or questionable, requiring that this part of the discussion be brief. To date, domestic beans (Phaseolus vulgaris) have been identified at just four sites, all in rock shelters, of which three are in Las Animas County, Colorado and one is in the Oklahoma Panhandle (table 1). Beans at the Colorado sites are associated with the Diversification period, including three from Trinchera Cave that were recently dated to cal A.D. 1210-1275 (Zier 2015). Beans are known to have been found at Kenton Caves, Oklahoma but are uncommon and remain undated. In fact, perishable materials from the Early Archaic through Diversification periods have been dated at Kenton Caves, but no dates have been obtained from cultigens (Lintz and Zabawa 1984; Rexroth 2010). Wills (1988:153) believes that beans (and squash) have been present in the American Southwest as long as maize, and if so could be 3,000 years old or older in the region (see also Minnis 1992 for a concurring view). However, beans probably did not reach the northern Southwest until circa A.D. 300-600 (Wilshusen and Perry 2012). The late dates in the Apishapa region are therefore not surprising. Neumann (2005), in reference to early farming in Africa, has noted that "the absence of evidence does not inevitably mean evidence of absence." This statement is certainly true, especially in an archaeological context. Burrillo (2016) has observed that beans are lacking in ligneous or "woody" content, rendering them more prone to deterioration under most archaeological conditions than either maize or squash. Cultivation of beans may have been more widespread in the region than current evidence would suggest, but at this time little else can be said of this crop and the role it might have played in the Apishapa subsistence economy.

Squash or gourd (Cucurbita sp.) remains consisting of varying combinations of seeds, stems and rinds are reported from five sites in the study area and are abundant at two of the sites, Medina Rock Shelter in Las Animas County, Colorado and Kenton Caves in Oklahoma. But there is no firm evidence that these plant remains are not those of undomesticated gourds, which are common throughout the central and southern plains including southeastern Colorado and adjacent parts of New Mexico and Oklahoma. Thus, it cannot be stated with certainty that domesticated squash were ever adapted into the prehistoric economy of the study area.

Unlike beans and squash/gourds, maize or corn (Zea mays) remains have been reported at 40 sites (including one rock shelter recorded as an isolated find) within the Apishapa region. These localities are widespread, occurring in six Colorado counties as well as Union or Colfax County, New Mexico and Cimarron County, Oklahoma (one site in each state). The data from these sites are hardly comparable. The initial discoveries of maize consisted of cobs and other plant parts that were readily identifiable with the naked eye, and occurred in the course of both professional surveys and nonprofessional investigations. These early discovery sites, with the exception of the Snake-Blakeslee site, were in rock shelters where preservation of perishables was exceptionally good. Most of the more recent discoveries, within the past three decades or so, have been the result of professional excavations in which enhanced recovery of macrobotanical remains and/ or pollen was practiced. Rather than whole corn cobs, these investigations have tended to yield small numbers of cob fragments or individual pollen grains. The effects of methodological evolution may be illustrated in the excavation history of the Avery Ranch site on the Fort Carson Military Reservation south of Colorado Springs. Three excavations were conducted between 1965 and 1986, but only during the final project were flotation samples removed from features and subjected to macrobotanical analysis. This analysis yielded evidence of maize in the form of numerous cob fragments and a few whole kernels from multiple proveniences, while the previous excavations produced no evidence of maize whatsoever (Ireland 1968; Watts 1971, 1975; Zier et al. 1988, 1990).

As an indicator of where maize really occurs in the region, table 1 is as complete as current databases allow-and the information it presents is fundamentally biased. It is skewed toward (1) sites in certain canyon settings where dry rock shelters have preserved botanical remains, (2) sites in areas 


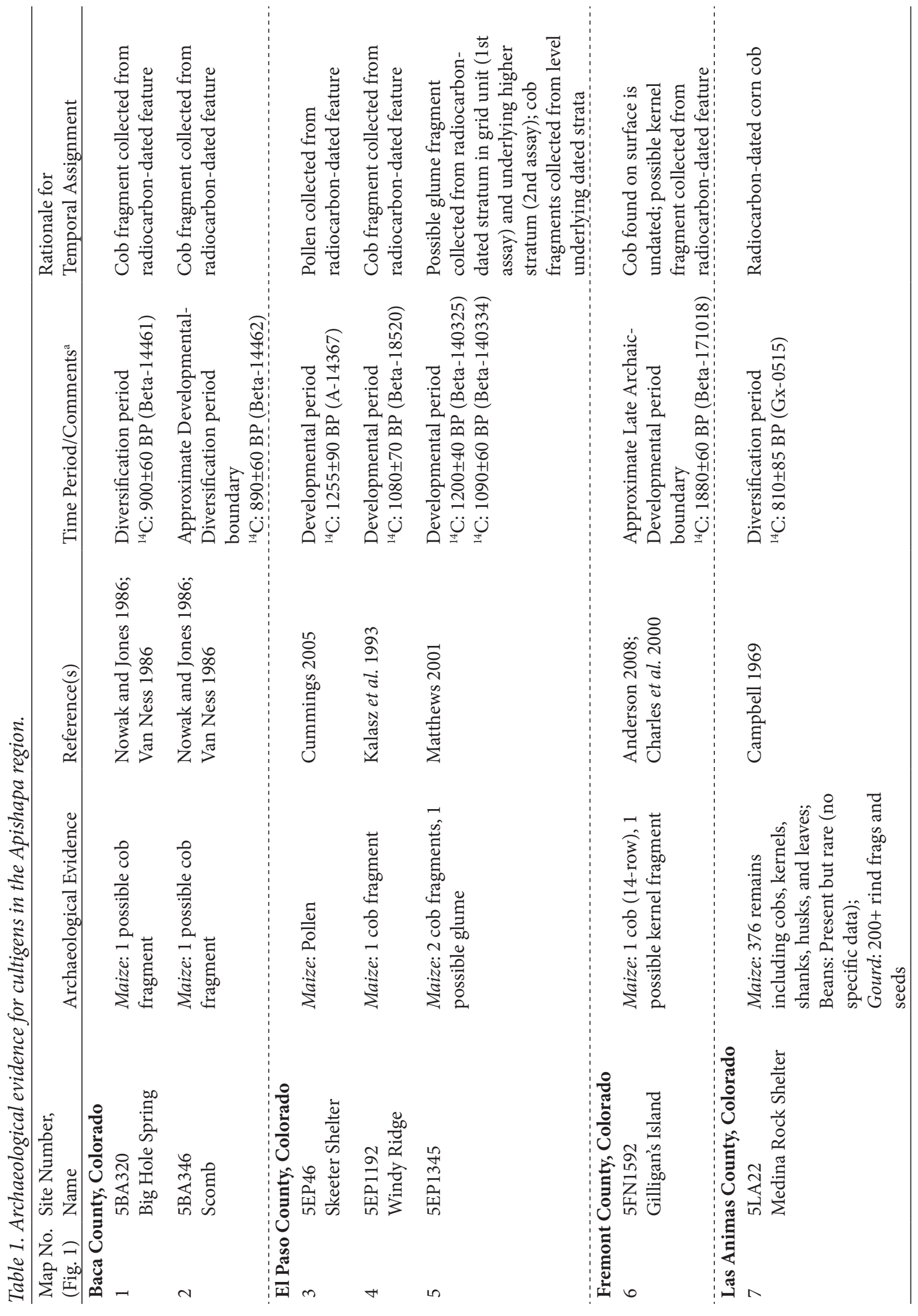


Role of Horticulture in the Apishapa Region

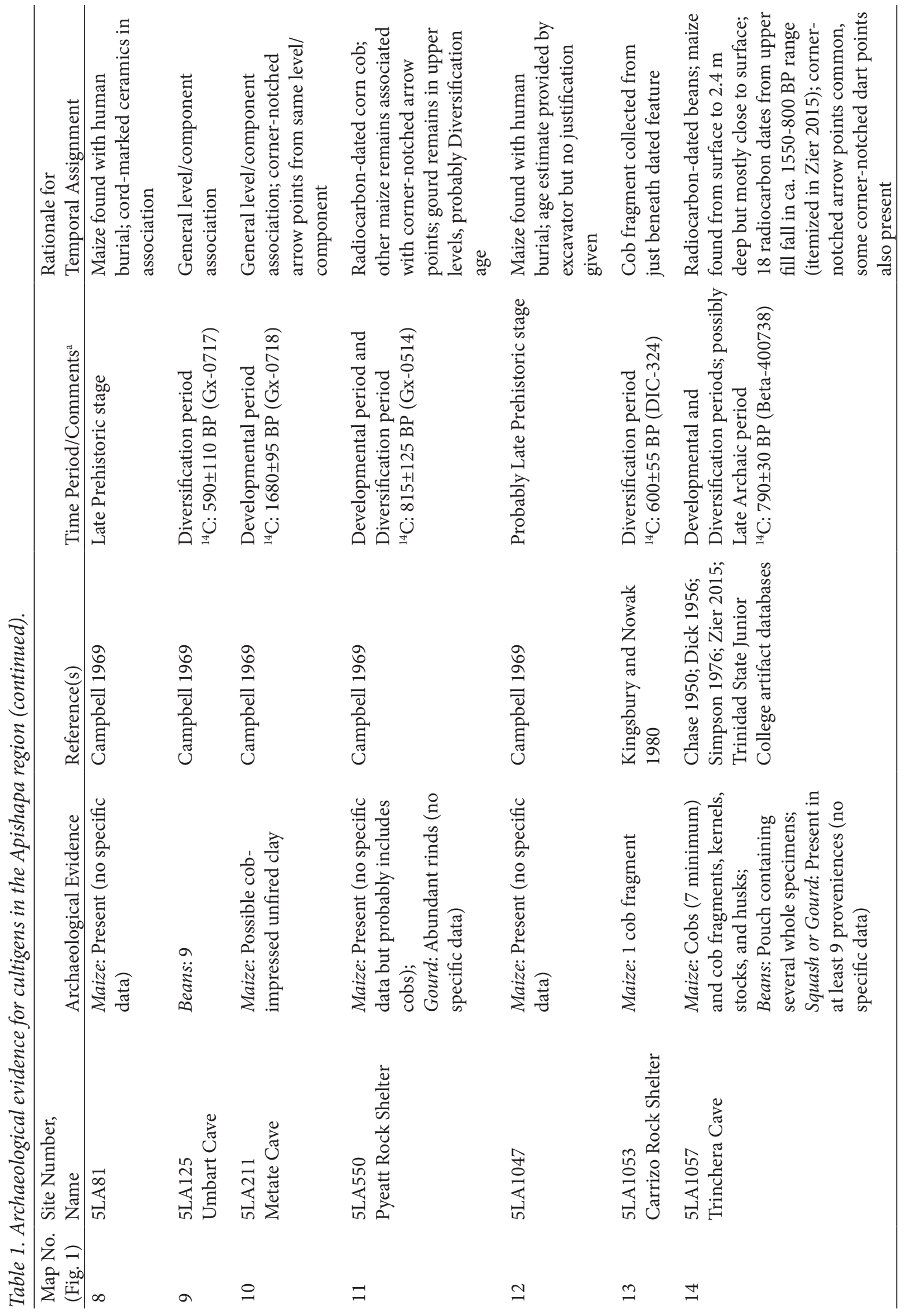




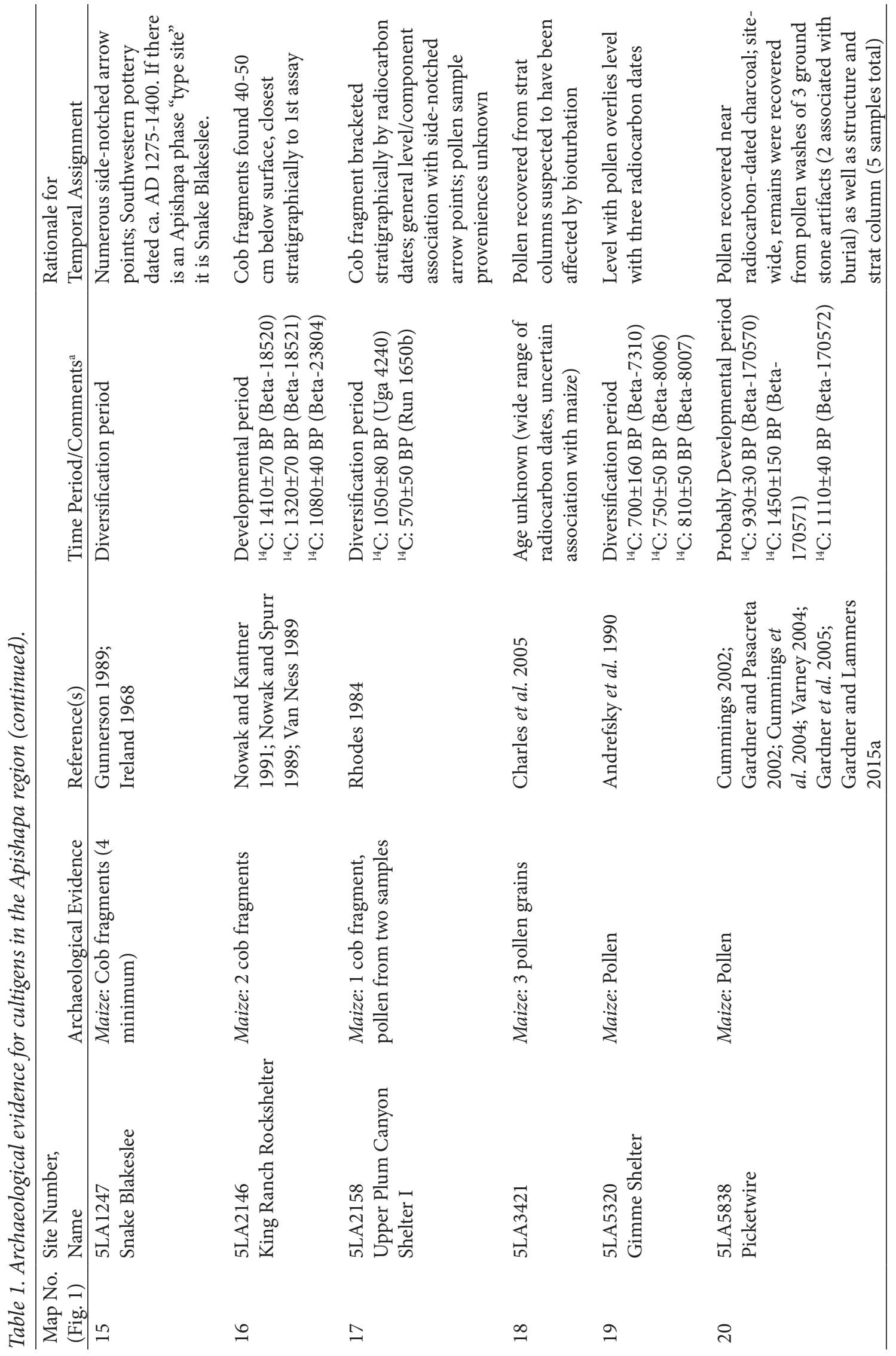




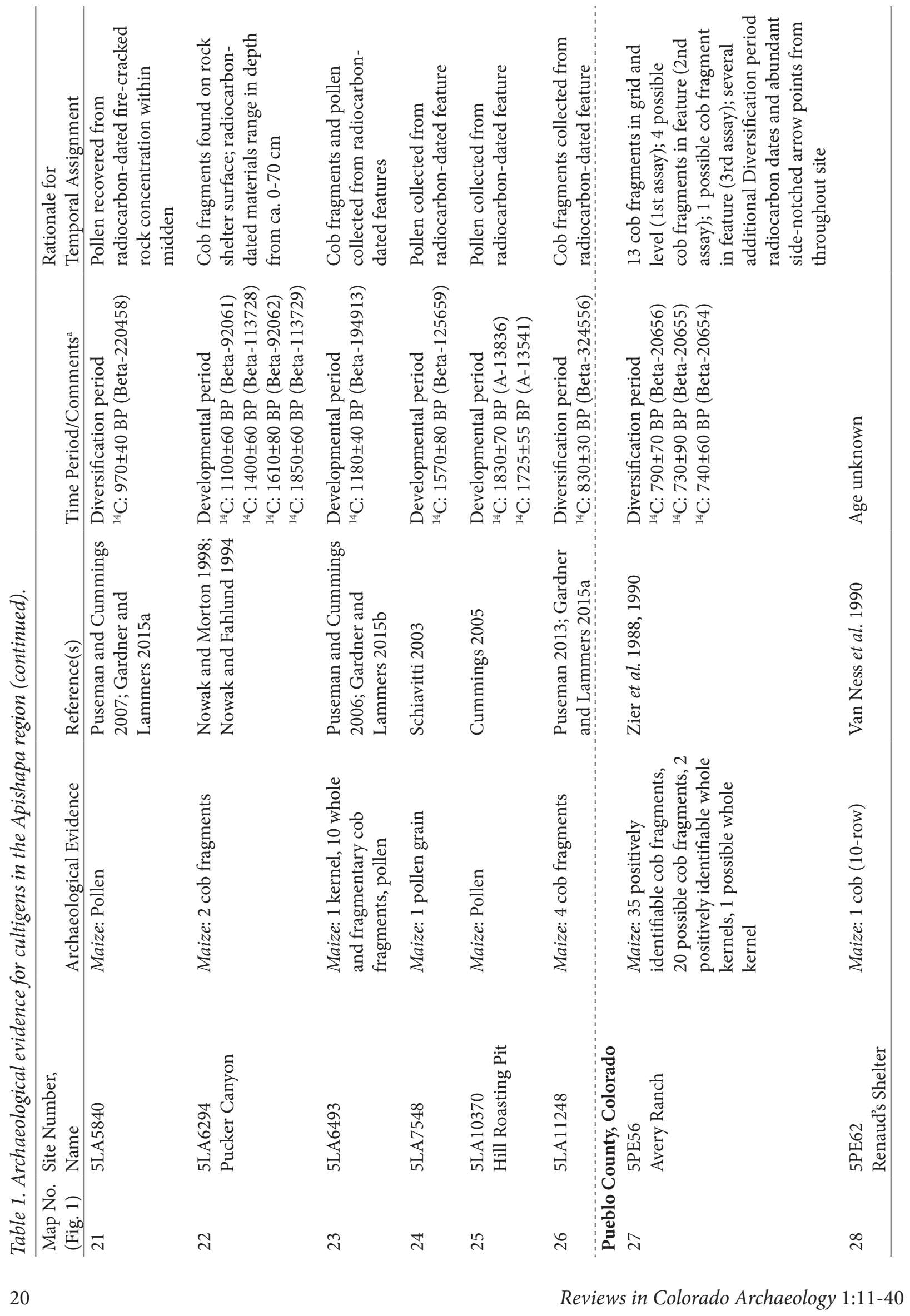




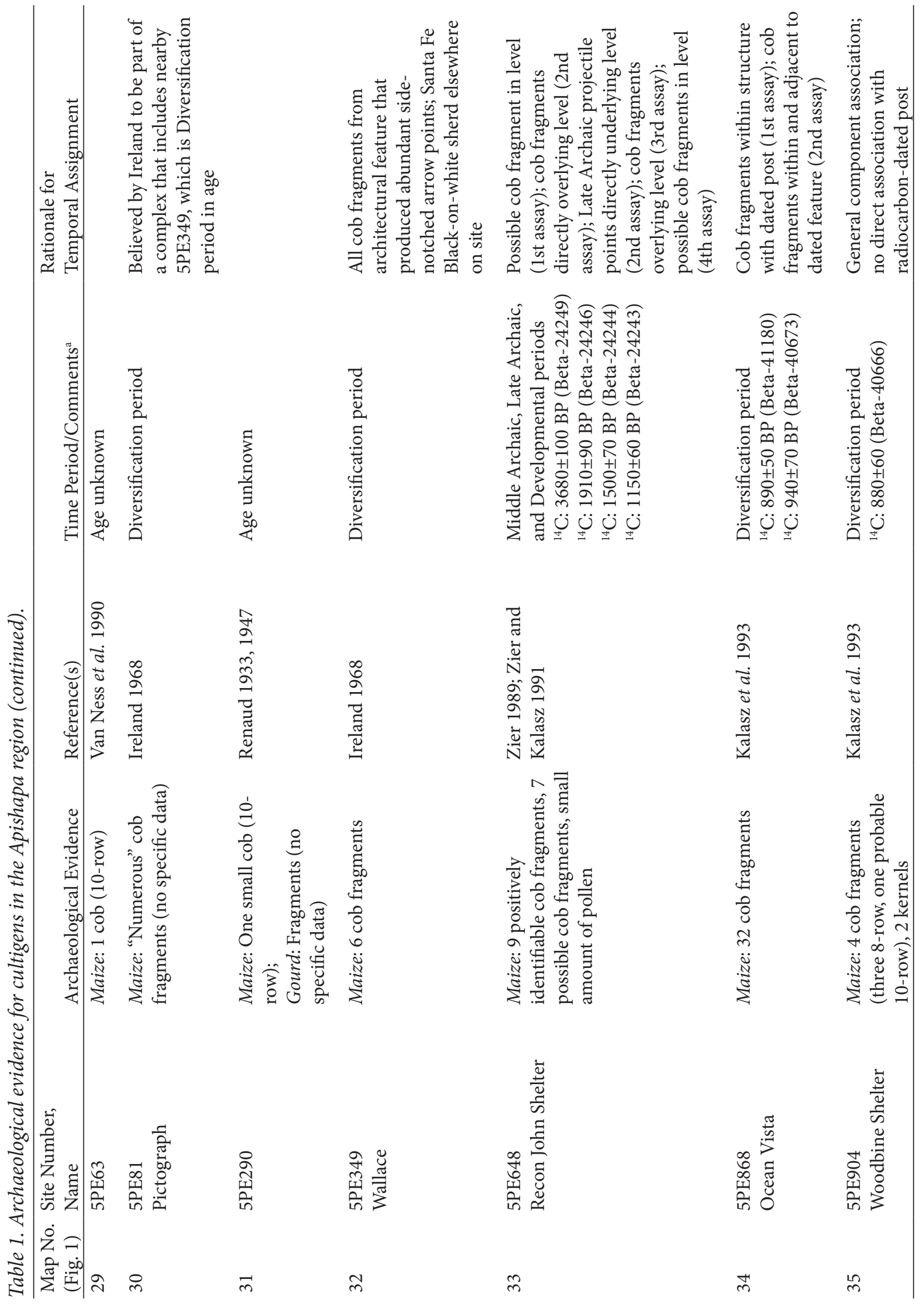


Role of Horticulture in the Apishapa Region

Zier
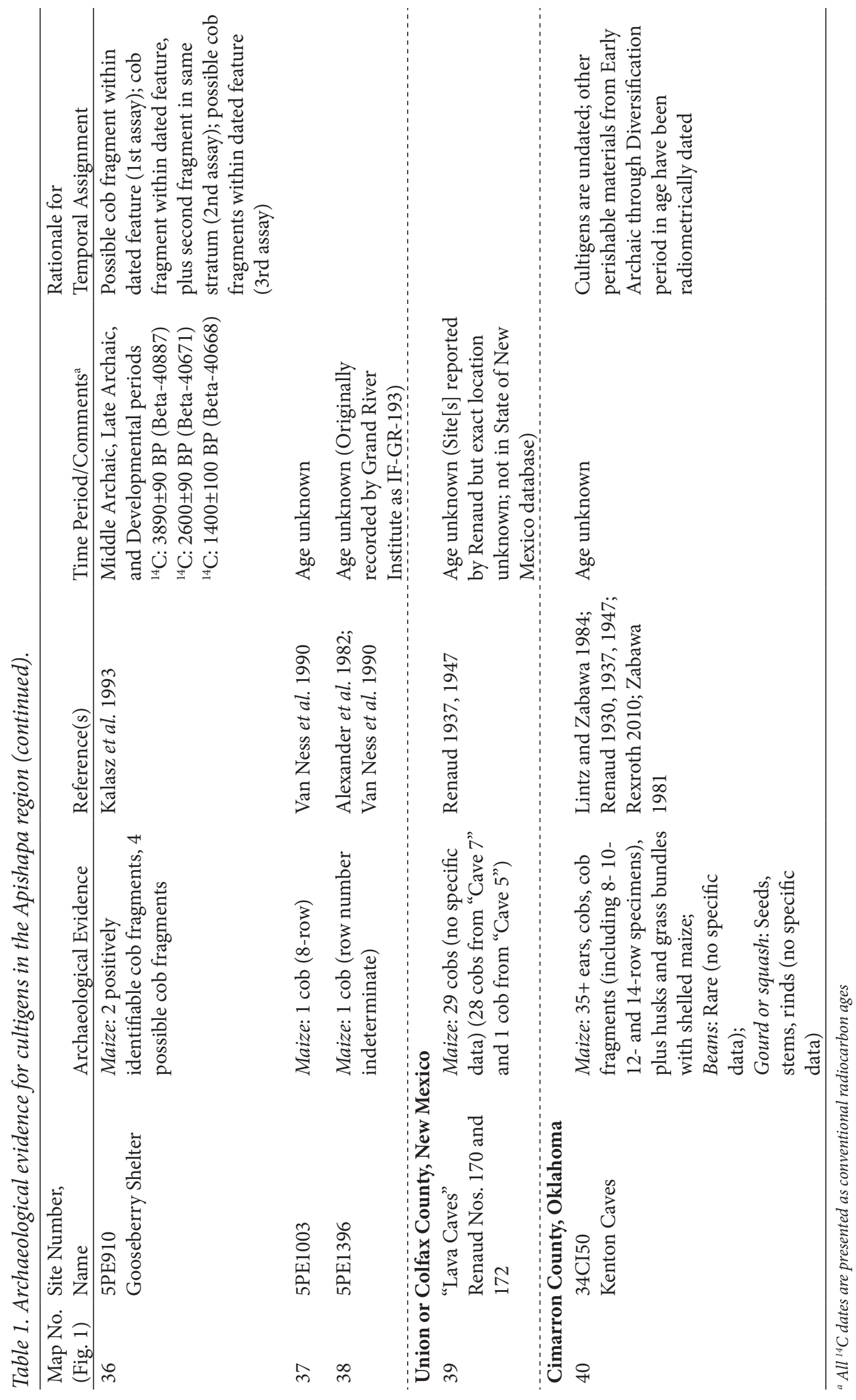
where contract-based investigations have been concentrated, such as the Fort Carson Military Reservation and Pinon Canyon Maneuver Site, and (3) sites that have been investigated within the past 30 years. These limitations notwithstanding, it is apparent that maize in some form occurs in the archaeological record throughout much of the Apishapa region, and it may also be stated with some degree of confidence that its distribution would be more widespread if the geographical foci of research were to shift within the region.

Maize in the study region is derived from both dated and undated contexts. Some components are radiometrically dated but it is important to note that in nearly all cases it is the components that have provided datable materials such as charcoal from hearths; only two direct dates from maize remains are available. Ages of other components are based on artifact associations. Fifteen site components that have yielded dated maize remains are of Diversification period age, i.e., Apishapa phase. It is clear that maize was well established in the area by the preceding Developmental period, for which at least 14 components are represented. Dated maize at one site occurs at the approximate Developmental-Diversification period boundary, and at two other sites the remains may only be assigned to the Late Prehistoric stage, with no finer chronological breakdown. Late Archaic evidence of maize is limited to two shelter sites on the Fort Carson Military Reservation, where cob fragments were found in radiocarbon-dated stratigraphic contexts, while a third Fort Carson shelter produced maize dated to the approximate Late ArchaicDevelopmental period boundary. Trinchera Cave in Las Animas County may also contain Late Archaic maize although dating is uncertain. Scant evidence of Middle Archaic maize at the same two Fort Carson sites with Late Archaic remains almost certainly reflects contamination due to bioturbation or human disturbance (Zier 1989; Kalasz et al. 1993). Finally, eight sites in the Apishapa region have yielded maize that is undated. An examination of table 1 suggests that most dated evidence of maize in the Apishapa region falls within the range 1400-600 B.P., or approximately cal A.D. 550-1350.

Reviews in Colorado Archaeology 1:11-40

\section{Maize Origins in the Prehistoric Southwest}

That the Southwest was the original point of entry for maize into the present U.S. has long been acknowledged by students of early agriculture in North America (Wills 1992). In the eastern U.S. there is no positive evidence of maize predating ca. 2000 years B.P. and its presence is not firmly established until about A.D. 200 (Adair 1988; Blake 2006; Wills 1992). The dates for earliest maize in the Southwest are far older (below), predating the eastern U.S. by as much as two millennia. It was certainly from the Southwest that maize spread to the central and southern Plains including the Apishapa region, where evidence now indicates that it was present during the Late Archaic period.

Based on evidence from Bat Cave in western New Mexico, archaeologists long believed that maize had been present in the Southwest for about 4,000 years (Dick 1965; Mangelsdorf et al. 1967). However, a careful reexamination of the Bat Cave data by Berry (1985), which identified errors both in assignment of stratigraphic associations and the actual approach taken to radiocarbon dating, significantly reduced the probable maximum age of maize at the site to about 2500 years B.P. Perhaps ironically, evidence that has come to light from around the Southwest since Berry's publication has tended to walk back the age of early maize in the Southwest to between 3500 and 4000 B.P., perhaps earlier; the oldest dates just don't come from Bat Cave. Wills (1992) describes "incipient food production" in the Southwest beginning around 3500 B.P. and believes maize was widespread by around 3000 B.P., possibly entering the Colorado Plateau a century or two later (see also Wills 1988). Likewise, Huckell and Toll (2004) place early maize cultivation in the Southwest between 3000 and 3500 years B.P. Fish (2004) believes maize was present as early as 4000 B.P. and was widespread by 3000-2500 B.P. Similarly, Doolittle and Mabry (2006:110) believe that maize had entered the Southwest from Mexico by $4200-4100$ B.P., and Huckell (2006:106) observes that dates from the Colorado Plateau indicate that its spread from the southern basin-and-range region into much of the Southwest occurred rapidly.

The identification of specific maize varieties in the study area is problematic at best; the significance of the variability that exists in the archaeological 
record, in terms of both genetic evolution and human subsistence, is nearly impossible to assess in the absence of comprehensive analysis of the existing collections. Two varieties that have been identified repeatedly in the region are Chapalote and Maiz de Ocho, the former long thought to be derived from an ancient Mesoamerican variety and the latter a more recent Southwestern strain (Krishna 2013; Fish 2004; Wills 1992). Other varieties have also been identified, and the criteria for identification are uncertain and have been inconsistent over time. W. C. Galinat (personal communication to Campbell [1969]) identified five varieties of maize (including the two named above) from Medina and Pyeatt rock shelters in Las Animas County; several varieties of maize are reported from Kenton Caves including 8-, 10-, 12-, and 14-row specimens (Lintz and Zabawa 1984). However, at the current level of analysis, row number is of limited utility in identifying specific varieties of maize because, as Toll (1990:276; see also Toll et al. 1985) has pointed out, variability within a population of maize is common, and in the more primitive types of maize "genetic plasticity and response to climatic stress are expressed in varying cob and kernel size, row number, and number of cobs per plant." Huckell (2006:104-105) acknowledges the tremendous variation in row number in the Southwestern Late Archaic (4 to 22 rows, with a mean of 12), asserting that row number tends to increase over time, probably as a result of human selection.

Adams (1994) states that nine distinct varieties of maize have been identified in the prehistoric Southwest, reflecting both diffusion from Mexico and genetic development within the Southwest. Krishna (2013) notes further that a wide variety of maize types was grown by Native Americans between Mexico and the northern Plains of the U.S., and that these types were derived from at least 25 primary varieties. Discussing Southwestern maize in general, Huckell (2006:105) cautions against using modern race identifications to classify prehistoric maize. She notes, for example, that isozome studies have demonstrated that Chapalote is not an ancient race of maize at all. It cannot be assumed that the earliest maize to diffuse into the Apishapa region from the Southwest was particularly well suited to the local environmental. Better and more productive strains may have developed in situ over time just as newer strains from the Southwest (or, in Late Prehistoric times, even the Central Plains) may have followed. Thus, the question "What kind of maize was grown in the Apishapa region?" defies any sort of definitive response although it may be asserted that a great deal of morphological variability exists within the rather meager regional archaeological assemblage.

\section{Somewhere in the Middle Between Foraging and Agriculture}

In a provocative article published over three decades ago, anthropologist Jared Diamond (1987) declared the adoption of agriculture by hunter-gatherers to be "the worst mistake in the history of the human race." Diamond cited plenty of evidence for his position, much of which is supported by anthropological research. Compared to hunter-gatherers, primitive farmers: worked harder for their food and therefore had less leisure time; were more disease-prone because they lived in crowded settlements; partook of a less varied diet, with negative consequences in terms of overall health, physical stature, and life expectancy; and lived in societies characterized by class divisions and pronounced social and sexual inequality. Why, then, did so many hunter-gatherer societies the world over decide to become farmers?

The answer to that question is far more nuanced than Diamond's brash assertion. Minnis (1985), as if anticipating Diamond, noted that the concept of hunter-gatherer abundance has been somewhat romanticized and thus trivializes the realities of fulfilling subsistence requirements. And Barker (2006:410-411) warns about seeking broad explanations for the foraging-to-farming transition process because doing so ignores the incredible diversity that exists among primitive societies worldwide. Barker cites multiple factors, both environmental and social, that may have influenced the process, implying that individual circumstances created variability in the process itself. It must also be noted that the advent of agriculture assumed two basic and fundamentally different forms: in situ domestication of plants, and adoption of domesticated plant use by former hunter-gatherers that were not involved in the actual domestication process. It is the latter scenario that concerns us here.

The Apishapa culture area lies along the western, 
higher portion of the approximate CentralSouthern Plains boundary (a boundary not always well defined), adjacent to the northern Southwest. Keeley (1995) has observed that proto-agriculture is often encouraged in high-risk environments characterized by low or variable rainfall and located in the low to middle latitudes. Domesticated plants typically spread to such areas by diffusion, rather than as a result of actual human colonization; and, the diffusion process tends to be very gradual (Price and Gebauer 1995; Price et al. 1995), which reflects both the inherently conservative nature of cultures and, in many cases, the time required for cultigens to become fully adapted to new environmental conditions.

The descriptions of Minnis $(1985,1992)$ and Wills (1995) regarding the gradual adoption of maize agriculture by hunter-gatherers in the Greater Southwest are particularly germane. These researchers have observed that a period of approximately 2,000 years passed during which maize was grown by hunter-gathers who experienced minimal economic or lifestyles changes. So-called casual cultivation was integrated into the hunter-gatherer economy without significant modifications in either food processing technology or food consumption behavior (see also Wills 1992). Minnis (1985:310) has, in fact, characterized the introduction of domesticated plants to the Southwest as a "monumental nonevent." The archaeological evidence from the Apishapa region, while rather scant, generally parallels that of the Greater Southwest in that maize was at least a minor component of the subsistence economy from sometime in the Late Archaic period until the end of the Apishapa sequence, circa A.D. 1450, a span of at least one-and-a-half millennia. Of course, in the Southwest full agricultural dependence and sedentism were the eventual outgrowth of the process of the adoption of cultigens. The Apishapa sequence, conversely, terminates with apparent abandonment of the region.

Foragers do have sound reasons for adding cultigens to the hunter-gatherer economic base. Even in favorable environments-but especially in marginal (for example, semi-arid) environmentsfood availability is rarely consistent and can fluctuate widely from one year to the next. According to Wills $(1992,1995)$, the addition of cultigens during critical periods was strongly risk-averse and allowed for more effective foraging-essentially, an intensification of an existing hunter-gatherer economic system that resulted in a more secure supply of food. As Barker (2006:392) has stated, foragers begin raising domesticated plants not in order to change their way of life, but to preserve it. It is noteworthy that the first cultigens adopted by foragers typically are primary food staples, such as maize, rather than delicacies (Keeley 1995). This was a process intended to increase the odds of survival; it was not about obtaining luxury foods.

In this discussion of hunter-gatherers shifting to a greater reliance on cultivated plant foods, the role of weedy annual plants should not be overlooked. Doolittle and Mabry (2006) present a strong case for the existence of proto-agriculture in the Southwest, defined as the protection, encouragement, and in some cases cultivation of native, economically important plants. Described as a fuzzy gray area between gathering and agriculture, this phenomenon is supported not only by archaeological evidence but also by ethnographic studies, and may reach as far back as 5000 years B.P. The important wild plant species in the Southwest (goosefoot, amaranth, Indian rice-grass, dropseed, tansy mustard, beeweed) are all native to the Apishapa region as well; goosefoot and amaranth seeds are particularly common in archaeological contexts (Zier and Kalasz 1999:122, 136-137, 218). Doolittle and Mabry (2006:112-118) conclude that prehistoric Southwestern hunter-gatherers were not only collecting and harvesting wild plants prior to maize cultivation but were engaged in active plant management-a form of low-level husbandry. A wide variety of environmental niches was used, especially locales that included high water tables, overbank flooding, runoff concentrations, and soils that retained moisture. The implications for the earliest adoption of cultigens are plain: among some foraging peoples, the transition to part-time horticulture could have been a nearly seamless process that, at least initially, involved few changes in social structure or mobility patterns.

Gardner and colleagues (2010), noting the co-occurrence of "Cheno-am" (Chenopodium sp.[goosefoot] and amaranth) seeds with maize remains in archaeological contexts, have suggested that wild food plants were intentionally grown and 
procured together in southeastern Colorado. They go so far as to insist that "mounting evidence" exists that Cheno-ams and maize were cultivated together during Late Prehistoric times. This assertion is probably overstated, but there is little doubt that a mixed economy was in place at this time, and intentional manipulation of non-domesticates may have been practiced.

Another perspective on what might be termed in between economies is provided by Roper (2007), whose area of study is the prehistoric Central Plains. Roper describes economies exhibiting food production systems that employed a combination of domesticated and wild plants. In terms of caloric intake such systems placed a greater reliance on wild plant foods, and tended to be associated with environments that were marginal for agriculture (similar to the high risk environments cited by Keeley). Because of environmental differences, the Central Plains region considered by Roper-lying east of the 100th Meridian-is far from a perfect analog for southeastern Colorado. However, certain archaeological implications of the economies she describes are worth noting. Roper observes that an evolving food production system with an increasing reliance on agriculture should result in a modified technology that includes new classes of artifacts; in the Central Plains, bison scapula hoes serve as an example. On a larger scale, the development of domestic food production would have led to an increase in sedentism, which in turn would result in a more visible archaeological record: territories within which people move tend to shrink, populations become more concentrated, and habitation sites become more permanent in conjunction with the development of land tenure systems.

Anthropologists disagree about the commitment required to raise domesticated plants effectively and the immediate effect on group mobility. For example, Bellwood (2005:26) notes that untended crops fare poorly and produce low yields. Conversely, Minnis (1992:130) claims that the constraints placed on group mobility as a result of cultivation have been overemphasized, stating that intensive labor is required only at the time of planting and harvesting. Furthermore, crops could be grown in the most favorable locations, thereby minimizing the chances of failure. That a continuum exists between fully mobile hunter-gatherers and sedentary farmers is certain, and it is only logical that any foraging culture, like the Apishapa, that began using domesticated plants made certain adjustments to their patterns of movement. This subject is explored in greater detail below.

\section{Maize Horticulture in the Apishapa Region}

As has been shown, the chronology of cultigen use in the Apishapa region is reasonably well understood: maize was present by sometime in the Late Archaic period, had become established by the Developmental period, and was fairly widespread during the Diversification period, which terminated with abandonment of the region. The presence of beans can be confirmed only for the final period of the cultural sequence. The motivations for regional hunter-gatherers to adopt small-scale horticulture are more difficult to pin down. As has been shown, foragers in marginal environments may begin cultivating domesticated plants simply as a hedge in order to ensure a more stable food supply. In other words, external forces do not necessarily have to be in play. Still, variables typically associated with the advance of primitive horticulture need to be considered. Most frequently cited in the anthropological literature are human migration, environmental change, and internal population increase.

The first variable-in-migration of agricultural peoples from somewhere outside the Apishapa region-can be dismissed rather easily. The Arkansas River basin east of the Rocky Mountains has a long and well-documented history of in situ cultural development (Zier and Kalasz 1991, 1999). While it is unrealistic to believe that population movements in the general region did not occur through time, the archaeological record is one of long-term stability with no evidence of significant or sudden influxes of new cultural traits. The fact that archaeological evidence of maize is minimal during the Late Archaic period, and builds gradually over a period of about two millennia, further suggests diffusion - undoubtedly from the adjacent northern Southwest-rather than human migration.

Environmental change merits more careful consideration, and indeed Barker (2006:398) claims that, on a global scale, the key driver of changes in 
subsistence behavior is always climatic change. On a global scale this is probably true, for example, as one considers the Neolithic Revolution that occurred in many places throughout the world as Pleistocene conditions gave way to the Holocene. On a local or regional level it is still incumbent to identify specific environmental trends that may have encouraged changes in economic systems. Gilmore's (2008) paleoclimatic reconstruction covering the last 3,000 years in eastern Colorado, outlined above, more than spans the full chronological range of known cultigen use in the region. The earliest and rather meager evidence of maize use falls within Gilmore's Terminal Archaic Drought, which dates ca. 250 B.C.A.D. 100. Maize evidence remains scarce during the subsequent two centuries as harsh climatic conditions eased, then increases in frequency during the remainder of the first millennium A.D., corresponding generally with Gilmore's Early Ceramic Drought and subsequent First Millennium Amelioration. The Medieval Climatic Anomaly of the first half of the second millennium A.D., manifested regionally as prolonged but not necessarily unrelenting drought, also corresponds with significant archaeological evidence of maize use. More site components associated with maize date to this period (Diversification) than the preceding period (Developmental) although the contrast between the two is not great. The Diversification period terminates with the apparent human abandonment of the region, an event that corresponds very approximately with the end of the Medieval Climatic Anomaly.

In sum, only in a most general sense can maize adoption and environmental trends be linked in southeastern Colorado. Maize does first appear in the archaeological record during a period of drought, and does occur most frequently more than a millennium later during another period of drought. But its gradual acceptance in the region also spans intervals during which less harsh climatic conditions prevailed. The imperfections of the archaeological record itself may account for the absence of a more satisfying correlation between regional maize development and climatic shifts. A more likely explanation is that the final variable named-population increase-was the most important driver of maize adoption.

Gilmore (2008:87-122) has developed human population growth curves for eastern Colorado based on summed probability distributions of calibrated radiocarbon ages. In the Arkansas River basin, his data show a gradual increase in population during the Late Archaic period, until about A.D.100, followed by a decline that continued until ca. A.D. 400. From that time until around A.D. $1250 / 1300$, population increased steadily, far surpassing levels seen previously in the region. Then, beginning in the thirteenth century, human numbers dropped precipitously until about A.D. 1500 by which time the region appears to have been virtually abandoned. Correlations between climatic fluctuations and population trends prior to about A.D. 1000 are credible, particularly during the Early Ceramic Drought, during which time population numbers sagged, and the subsequent First Millennium Amelioration when numbers recovered and surged. The post-A.D. 950 Medieval Climatic Anomaly did not suppress population numbers for about 300 years but, as previously noted, had the ultimate effect of forcing abandonment of the region, in a demographic trend that encompassed the thirteenth through fifteenth centuries. It is somewhere around the time of the first discernible increase in population, during the Late Archaic period, that maize first appears in the southeastern Colorado archaeological record, and it persists throughout the course of the Developmental and Diversification periods.

So how did these variables-climate, population change, and maize adoption-interact? Human beings, like most animals, naturally overreproduce to the extent that external conditions permit (Dumond 1972:287; Hassan 1981:164-165; Hayden 1992). Population numbers will therefore tend to rise until a countering force, typically environmental in nature, causes the trend to be muted or reversed. The population curves for eastern Colorado (Gilmore 2008:87-122) indicate that the region's hunter-gatherers existed in a state well below the carrying capacity for millennia, with human numbers beginning to increase substantially only near the end of the Late Archaic period. Those numbers continued an upward march for the subsequent 1,400 years although a centurieslong interval during which population numbers dropped in the Developmental period suggests that the region had reached its carrying capacity, which 
was modified downward as climatic conditions deteriorated. When climatic conditions eased, the population responded by increasing once again, then eventually plummeted as the carrying capacity was again reduced by environmental factors.

Maize cultivation does not occur in an ecological vacuum. Beyond the confines of the irrigated Arkansas River Valley very little corn is grown in the region today, and in fact most of the Apishapa culture area that is presently used for agriculture is given over to livestock grazing. Rainfall is light, variable, and unpredictable; many soils, particularly in upland settings, are thin and rocky; and significant elevation variation exists throughout the region, with implications for length of frost-free growing season. Gilmore (2008:68), believing that areas at higher elevations favored maize growing because of greater precipitation, observed that most sites in eastern Colorado with evidence of maize lie at elevations greater than $5500 \mathrm{ft}$, with some above $6000 \mathrm{ft}$. In fact, an examination of records for individual sites in the Apishapa region indicates that those associated with maize occupy a wide elevation range, from under $4500 \mathrm{ft}$ to $6440 \mathrm{ft}$, with an average of $5300 \mathrm{ft}$. More than anything else, maize sites appear to mirror the overall topographic tilt of the region, with the highest occurring along the western margin (El Paso, Pueblo, and Fremont counties) and the lowest in the east (Baca and eastern Las Animas counties). While maize horticulture does not seem to have been restricted by the higher western elevations, neither was it especially favored in these areas. Most likely, in semiarid southeastern Colorado maize was grown in localities where water was naturally concentrated. It is unlikely that upland areas lacking naturally concentrated water were planted in maize for such a proposition would have been too risky. The actual amount of precipitation received in a given area was probably of little importance, and therefore elevation was also not important as long as the growing season was not compromised.

Given the near-total absence of relevant archaeological data, we can only speculate as to the specifics of maize horticulture. As noted previously, because horticulture was not practiced intensively in the region, the most favorable locations would have been available (Minnis 1992:125). These areas logically would have been those with reliable surface and/or ground water, for example, floodplains of permanent watercourses such as the Purgatoire River. It is unknown if water control systems were established for the purpose of floodplain farming; if they were they were probably simple, considering that the societal commitment to growing maize appears to have been limited. Ak-chin farming may also have been practiced. In this method-long common among the Hopi in northeastern Arizonacrops would have been planted on alluvial fans at the mouths of side drainages, usually at the margins of a main valley at points where floodwaters slowed and spread out. An advantage of this approach to farming is that it requires little or no water control.

Considering the long history of low-level maize use in the Southwest, and the proximity of the Southwest to the Apishapa region, it is reasonable to assume that maize was present prior to the terminal Late Archaic although this has not been demonstrated archaeologically. Regardless, the mere presence of maize in the Southwest and adjacent Plains areas need not be explained as a response to population pressure. Maize probably diffused rather easily through these arid and semiarid regions among groups long accustomed to manipulation of various wild plants. It was not until the terminal Late Archaic or shortly thereafter, as the southeastern Colorado population began rising to levels not previously reached, that maize assumed a new importance. Once established as an integral element of the economy, its use in the region was steady although it never became a dominant element of the prehistoric diet. Although the archaeological evidence is ambivalent in this regard, cultivation of maize probably intensified over the course of the Diversification period in conjunction with steady population increase and climatic deterioration. Beans were supplementing maize and wild plant foods by this time although their overall impact on human caloric intake is impossible to gauge given the dearth of archaeological evidence.

A proposed scenario for the introduction and use of maize in the Apishapa region, and its relation to environmental change and human demography, follows.

Late Archaic Period

Maize diffused into the Arkansas River basin 
and other semi-arid Plains areas adjacent to the Southwest (for example, the Antelope Creek region of the Texas Panhandle), in a process that may have been facilitated by the ongoing manipulation and use of wild plant foods by local foragers. Economic systems were little altered as a result. There is no archaeological evidence that maize amounted to more than a very minor element of the human diet and may not have been consumed at all by some people. The small quantity of maize that has been found archaeologically in Late Archaic components suggests that no adjustments in mobility were made to ensure crop survival. The structure of the local foraging economy is largely unknown although it probably keyed on the vast network of canyons and adjacent uplands which provided a diversity of microenvironments, with implications for both plant and animal resources. The open steppes within the canyon country, and those extending to the north, east, and south, were used less intensively as suggested by the reduced plant diversity in those areas and relative scarcity of large mammal remains (e.g., bison and pronghorn antelope) in Archaic sites. Seasonal forays into the mountains bordering the region to the west may be assumed although archaeological evidence of such movement is unclear. Winters were probably spent in the valleys of major rivers such as the Purgatoire and Arkansas. The canyon country associated with the former stream, as well as the canyons of other Arkansas River tributaries, would have provided abundant rock shelters for seasonal occupation, and indeed there is ample archaeological evidence of just such use in various places throughout the region (Zier and Kalasz 1999).

\section{Developmental Period}

During the Developmental period, southeastern Colorado populations increased as the terminal Late Archaic drought subsided, then declined as drought reasserted itself, then increased steadily throughout the latter half of the period as the climate ameliorated once again. Archaeological evidence of maize is scant in the earliest part of the period but increases after $c a$. A.D. 550. The evidence is widespread throughout the region but thin; at sites where maize has been found the remains are usually scant. As noted, the occurrence of maize does not mirror climatic trends in any discernible way, but more closely tracks fluctuations in human population.

Lintz (1984:387-388) presents a long list of possible responses that may be adopted by populations existing under stress conditions where the carrying capacity has been reduced by such variables as drought. Among these responses, several may have come into play in southeastern Colorado: redistribution of population; lowering of population density through reduction in population size by various means, either voluntary or involuntary; lowering of the living standard through dietary changes; increased procurement of resources; increased use of stored reserves; and expansion of trade networks to access resources in adjacent regions. To this list may be added adoption of technological innovations to increase productivity and/or storage capabilities. Lintz (1984) observes that populations may even become extinct, suggesting that no response or adjustment may be adequate. Citing Minnis (1981), Lintz (1984:388-389) goes on to note that populations will tend to first choose the response that will least affect the overall biological system or cultural system of the group. In other words, cultures are by nature conservative and will change in ways that change them the least.

It is clear that one response to stress early in the Developmental period, during the Early Ceramic Drought, was population reduction, although the mechanism(s) by which this occurred is unknown. Technological changes during the Developmental period are clearly evident in the archaeological record: both ceramic and the bow-and-arrow technology entered the region during the first half of the period, reflecting technological innovations that occurred over broad areas of western North America at this time. Less certain is the extent to which these innovations actually reflect the subsistence needs of stressed populations. There is little doubt that the use of ceramic vessels increased both cooking efficiency and storage capabilities (Gilmore 2008:32-44) although, in southeastern Colorado, Developmental period ceramics are a relative rarity in archaeological sites, and when pottery is found it is suggestive of very limited vessel numbers. From a local standpoint, ceramic technology appears to be an occasional indulgence, 
perhaps somewhat experimental in nature, rather than a newly perceived necessity. Unlike ceramic technology, bow-and-arrow technology swept the region and in a very short time largely supplanted the atlatl and dart, which had prevailed for millennia. It certainly increased hunting efficiency among nomadic peoples everywhere. However, its rapid spread and widespread acceptance more likely reflect the obvious benefits of a new and improved technology than the nutritional needs of stressed populations. Gilmore (2008:29-30) suggests that bow-and-arrow technology already existed in Archaic times but was not broadly accepted until the Late Prehistoric, the result of nutritional stress that required improved hunting efficiency. This argument is unconvincing and finds little support in the regional archaeological record.

In sum, there is little hard evidence to suggest that the local foraging-based economic system was fundamentally altered during the first half of the Developmental period, and the emergence of ceramics and the bow and arrow yielded a sort of cultural veneer rather than basic changes in subsistence practices. That maize was being grown locally-and more consistently than in the preceding period-is unmistakable, and its rise generally mirrors the climatic deterioration of the Early Ceramic Drought. In Developmental period archaeological contexts, the indications of wild plant food use greatly outweigh those of maize, the latter often not present at all. In fact, a remarkable aspect of macrobotanical analyses from excavations around the region is how many sites do not produce evidence of maize consumption while wild plant foods, such as goosefoot (Chenopodium sp.) seeds, are found consistently in abundance. It may have been during this period that some changes in mobility strategy were made in order to ensure that planted crops were given sufficient attention to ensure crop success, but these adjustments were surely minor as evidenced by the general scarcity of maize in the archaeological record. Maize growing was probably opportunistic and may often have failed, as foraging schedules were little altered from the Late Archaic period.

Population rebounded in the latter half of the Developmental period, and it is near the end of the period that we begin to see the beginnings of a significant settlement shift that intensified during the following period. As numbers increased, and pressure on food resources presumably rose, human use of the canyon ecosystem in southeastern Colorado began to intensify. It is reasonable to assume that the territories covered by individual groups were reduced in area, and the foraging model of settlement probably began to yield to something more closely resembling a collector model featuring longer-term residency in favored locations. Such a settlement shift would have facilitated the cultivation of maize as people resided for longer periods of time near localities where it was planted, affording opportunities to water, weed, and otherwise tend to the crops. However, while horticulture was a beneficiary of an evolving settlement system, it is doubtful that it was ever the primary objective.

\section{Diversification Period}

The fundamentals of Apishapa subsistence during the Diversification period are reasonably well understood. The economy is characterized by very broad-based hunting and gathering with a significant reliance on wild plant foods and game of all sizes, but particularly small animals. It was also opportunistic as indicated by the presence at certain sites of large quantities of butchered bison bone (Zier 1988, 1990; Kalasz et al. 1993). Maize is widely but thinly spread among Apishapa sites, but certainly not all sites.

The human population of southeastern Colorado rose steadily for the first approximately three centuries of the Diversification period while the climate deteriorated. This combination of natural and demographic processes undoubtedly placed increasing pressure on food resources which led to an intensification of exploitive behavior. Adjustments occurred in patterns of human movement and to a significant degree are reflected in the archaeological record. Archaeologists have long noted the tendency of populations under stress to coalesce into larger and more permanent habitations, and this may be true of both huntergatherers and incipient horticulturalists, although the tendency is by no means universal (Lee 1976:86; Plog 1974:77, 121; Vernet 2002; Zubrow 1972:277278). There are attendant implications for evolving concepts of territoriality and land ownership as 
populations become clustered and more sedentary. The tendency toward population coalescence would seem to be strongest in regions where food resources are unevenly distributed, i.e., where areas exist that are valuable enough in terms of resource potential that populations will cluster around them. The Apishapa region, with its numerous microenvironments concentrated within and near canyon networks, fulfills this criterion. Gilmore (2008:266) is correct in stating that populations under stress have the option of either coalescing or dispersing, but in a given area these options may be manifested as sequential responses, with coalescence an initial societal reaction and dispersal the ultimate sign of economic collapse.

Population aggregation is best reflected archaeologically in the appearance of stone enclosure sites. These sites, which assume a variety of physical forms, may be regarded as the hallmark of the Apishapa phase (Kalasz 1988, 1990), and while they occur in a range of open and sheltered settings, the largest and most prominent are nearly all found on the rims of canyons. No evidence of intra-group conflict has been recorded archaeologically, but if the sites are not truly defensive in nature, they are at least defensible. It is equally clear that they do not represent full-time habitation despite the superficial resemblance to village sites in the Central Plains and Pueblo Southwest. Most notably, these sites lack middens of the sort one would expect to find associated with villages with full-time inhabitants. Many sites actually exhibit a dearth of artifacts, and when middens do occur they tend to be thin sheets rather than significant concentrations of living debris. These sites are best explained as the physical manifestations of seasonal coalescence of small groups in areas where key resources were concentrated. These groups may have been related through kinship; for example, two probable households were identified at the Avery Ranch site, a canyon-rim stone enclosure site of moderate size on the Fort Carson Military Reservation (Zier et al. 1988, 1990). It is also possible that larger sites represent multiple kinship groups. The sites could well be indicative of ownership claims, or at least claims of proprietary access to the resources within defined territories. They may also signal a complete shift away from the forager model to the collector model of settlement, with implications for hunting- and-gathering domains of reduced geographical area (Gilmore 2008:48-52). These seasonal gatherings probably occurred during the summer, perhaps extending into the fall months. Maize cultivation would have become a more successful enterprise under such a settlement system, given the fact that people were present throughout much or all of the growing season. It is unlikely, however, that maize production was a key driver in the progression toward settlement coalescence (Gilmore 2008:267). Like maize, wild plant foods such as goosefoot and amaranth, which could have been tended and encouraged to some degree, may have been exploited with greater efficiency as a result of these settlement trends. While few storage features have been excavated in Diversification period stone enclosure sites, it appears that wild plant foods remained of paramount importance in the local diet.

Campbell (1969:391), reflecting on observations made in the canyon-mesa country of southeastern Colorado, stated that horticulture became "a fundamental part of the subsistence pattern during Apishapa [post- A.D. 1000] times. There is reason to believe that the part played by gardening may become more meaningful than foraging as a means of food acquisition..." He goes on to note that large Apishapa sites are situated consistently near arable land, a reference to canyon- and mesa-rim locations overlooking floodplains. Campbell was almost certainly wrong in his conclusions about heavy Apishapa reliance on horticulture, as has been shown by nearly a half-century of investigation in the region since the time of his research. The large volume of maize remains at Campbell's Medina and Pyeatt rock shelters definitely weighed on his opinion but a substantial comparative database of Apishapa-age sites that has since been accumulated shows that these sites are outliers and far from typical. The sites are instructive in other ways, however. The presence of numerous cobs with kernels intact clearly indicates-as Campbell (1969:84) himself noted - that crops were being grown locally, for imported maize would surely have arrived in shelled form. Well-formed, mature maize in abundance, even at a limited number of sites, also suggests that mobility changes had taken place which allowed the successful production of mature crops. In essence, Campbell was correct in 
asserting that the importance of horticulture had increased by Apishapa times, but he overstated the case, largely as a result of sampling error.

Archaeologists tend to view cultures as progressive, proceeding in a particular direction toward a logical final state. Regarding the Apishapa area, this sort of view invites comparisons with regions both to the east and southwest, where full agricultural dependency developed along with a sedentary lifeway. At the most, however, even with intensifying drought and populations higher than at any time in the past, Apishapa people remained essentially hunters and gatherers, albeit in the context of a modified economic system that deemphasized mobility to the extent that the settlement pattern may be described as semi-sedentary. Even as maize (and possibly beans) assumed greater importance in terms of caloric intake, its spotty presence in the regional archaeological record is still suggestive of food hedging-producing a crop as insurance against failure of traditional food sources-rather than a significant shift toward an emphasis on food production. Campbell (1969:391) dismisses the lack of obvious agricultural implements, such a bison scapula hoes, as a reflection of the fact that the canyon environments would not have required sturdy digging tools. This statement is inadequate, for a significant shift toward agricultural production would almost certainly have been accompanied by similar technological changes as occurred in the Central Plains (Roper 2007; Wedel 1986). Gilmore (2008:49) correctly notes that grinding stones increase in frequency in Late Prehistoric contexts, signifying intensified processing of plant-based foods. This phenomenon is consistent with the notion of generally intensified resource utilization during a time of population increase and climatic deterioration, but suggests only that plant processing intensified and not necessarily processing of cultivated plants.

Environmental deterioration in concert with population increase culminated in the abandonment of the Apishapa region in the fifteenth century. Given the long and evidently continuous record of human habitation in the region, this was a noteworthy event suggestive of a complete societal breakdown. While it is difficult to compare the degree of climatic deterioration with that of the northern Southwest, much of which was also abandoned in later prehistoric times, Gilmore's (2008:231-233) analysis and review makes clear that the warm and dry conditions of the Medieval Climatic Anomaly were hemispheric in scope. From a subsistence standpoint, maize horticulture would have been helpful during a time of environmental stress, but only up to a point-the point at which crops consistently failed due to environmental conditions, or were inadequately managed due to internal societal turmoil. The fact that the Apishapa region remained populated for 150 years after the abandonment of the Four Corners region argues against a heavy dependency on domesticated crops. On the contrary, it suggests that foraging for wild plant and animal foods remained economically predominant throughout although, in the end, these resources did also prove to be inadequate. The ultimate destination of the Apishapa people in the fifteenth century is not known, but logic dictates that movement was to the east toward areas where precipitation was greater.

In examining the cultural processes of the Diversification period, it is worthwhile to revisit the potential responses exhibited by populations under stress conditions, summarized by Lintz (1984:387388 ) and described in the previous subsection. That some of these responses occurred cannotbe disputed: population was redistributed, a process manifested initially as clustering, then ultimately was reduced through dispersal as people migrated out of the region; and resource procurement was intensified, a trend that included increased-but not dramatically altered-reliance on cultigens. Regarding other potential responses, the archaeological record is ambivalent, or has not yet been fully revealed. The capacity for storage of food reserves did increase as ceramics became more common and widespread than in the preceding period, and stone enclosure sites are known to have included storage facilities (Zier et al. 1988, 1990). Still, even in Diversification period sites, ceramics are something of a rarity, and the ubiquity of permanent storage facilities has yet to be demonstrated through archaeological investigation. Trade links between the High Plains and the Southwest, Pacific Coast, and other Plains areas are known to have been established by the Developmental period as evidenced by the occasional presence of exotic lithic materials, shell, and ceramics (Andrefsky 1990:IX-155-IX-156; 
Campbell 1969:89, 116; Sanders 1990:XI-29-XI31; Simpson 1976:155-156). However, there is no definitive evidence of stepped-up trade in the Diversification period, and certainly no indication that foodstuffs or other items essential to group survival were imported to the region. And, while the Late Prehistoric advent of bow-and-arrow and ceramic technology yielded advances in food procurement, processing, and storage efficiency, significant technological innovation did not occur. Regarding the possibility that living standards were lowered in a time of stress, the archaeological record is unclear, although by implication living conditions had deteriorated badly by the end of Diversification period. This might better be regarded as a consequence of climatic degradation and population pressure than a willful response. It would not be incorrect to describe the preabandonment Apishapa as practitioners of an in between economy (Roper 2007), considering the mixed hunter-gatherer-horticulture food base and the trend toward greater permanence in settlement, all in an environment that was marginal for agriculture under the best of conditions. But it was a conservative manifestation of such an economy with a stubbornly persistent technology and a continued emphasis on wild plant foods.

\section{Summary and Directions for Future Research}

The archaeological record shows that maize was present in the Apishapa region by sometime in the Late Archaic period and persisted through the end of the prehistoric sequence, $c a$. mid- fifteenth century. Maize is believed to have arrived from the northern Southwest by a process of diffusion, and was adopted into the local foraging economy as a means of ensuring a more secure supply of food. The advent and increased use of maize horticulture beginning in the Late Archaic period may very well have been a logical extension of a long-standing process of manipulation of wild plant foods, as is suspected in the prehistoric Southwest. The archaeological occurrence of maize increases through time, a trend that is generally coincident with apparent regional population growth. Although fairly widespread geographically by post-Archaic times, maize is not predominant in macrobotanical or pollen inventories from excavated contexts, and only occurs in relative abundance at a handful of sheltered sites where preservation of perishables was unusually good. Traditional exploitation of a range of wild plant foods as well as large and small animals remained the economic mainstay of the region through time. The increase in archaeological occurrences of maize in later components does suggest greater dedication to farming, and implies that some reorganization of scheduling and mobility took place, at least for certain members of the society. Coalescence of populations into fewer and larger settlements during the Diversification period probably facilitated the cultivation of maize (and very likely beans) but there is little evidence to indicate that food production assumed a significantly greater role in the Apishapa economy. The manner in which maize was grown, and the locations of fields, are unknown in the absence of archaeological data, but likely settings were localities where water was naturally concentrated, at least on a seasonal basis, such as floodplains of major watercourses and alluvial fans at the mouths of side drainages. The degree to which water manipulation techniques, such as irrigation, were employed in maize farming is unknown. If water control was practiced, its use was probably confined to the latter portion of the prehistoric sequence.

The established facts about early agriculture in southeastern Colorado are mainly geographical and chronological in nature: it is understood that agriculture was widespread throughout the region, and that it was practiced at some level over a span of at least 1,500 years. But, as noted above, the agricultural database suffers from several biases and can only be regarded as incomplete. Much remains to be learned. Studies that could significantly advance our knowledge of the subject are outlined here.

1. Radiometric dating of maize remains. As noted above, radiocarbon-dated site components with maize rarely include assays on actual maize remains (two examples only-Medina and Pyeatt rock shelters, plus dated beans from Trinchera Cave). Associations between dates and maize are therefore secondary although in many instances the associations seem quite reliable. Regardless, our grasp on the chronology of maize in southeastern Colorado is tenuous. 
Our understanding of the sequence of maize horticulture, including its origins, would be greatly enhanced by direct dating of cobs and cob fragments from sites across the region, extending from Kenton Caves in the southeast to Fort Carson in the northwest.

2. Genetic studies of maize. The difficulties attending the identification of maize varieties based on macroscopic analysis are described above. Associating cobs and cob fragments from archaeological contexts with previously identified races of maize is a subjective process, exacerbated by the fact that row number, upon which many identifications are based, may vary within a single variety of maize. Comparison of the genotypes of firmly dated maize remains from across the Apishapa region, and across the chronological span of documented maize use, with established genotypes representing the multiplicity of maize races in North America could greatly clarify our understanding of origins, in situ evolution, and influxes of genetic material from outside the Apishapa region over the course of the Late Prehistoric stage.

3. Comprehensive study of classic Apishapa sites. Large mesa top and canyon rim stone enclosure sites are emblematic of the Diversification period in the Apishapa area. As the primary physical manifestations of progressive population aggregation, they are also critical to understanding demographic and economic shifts that occurred during the period, and which culminated in abandonment of the region in the fifteenth century. But the function(s) of these prominent sites remains largely unknown, as does their association with possible intensification of maize horticulture. Campbell (1969), who recorded many such sites, speculated about their function almost a halfcentury ago, and we have made little progress since then. Modern archaeologists generally decry large-scale excavations as destructive and expensive, and mostly unnecessary for investigating specific research themes. It is worth noting, however, that we owe much of our understanding of Ancestral Pueblo population dynamics and economic practices to major, site-wide excavations that occurred at many locations over the past century. Open- air Apishapa stone enclosure sites have only occasionally been excavated on a large scale and much of that work occurred more than 40 years ago (Gunnerson 1989; Ireland 1968; Watts 1971, 1975). Comprehensive excavations of one or more such sites using contemporary field and analytical techniques would shed considerable light on economic activities and dietary spectrum (including the relative importance of maize and wild plant foods); seasonality of use and duration of occupancy; storage practices; group size and composition; intrasite work areas; and tool manufacture and use (lithic, ground stone, ceramic, bone).

4. Landscape studies. A region-wide examination of landscapes, incorporating information about soils, geology, geography, and botany, would contribute greatly to our understanding about not only agricultural potential but general human adaptation as well. Use of a GIS-based approach would be the most efficient means of undertaking such a study. Among the variables that might be considered are soil type, depth and fertility; elevation, slope and aspect; precipitation; distance to permanent and ephemeral water sources; and vegetation community distribution.

5. Reexamination of existing artifact collections. Clues to shifting economic emphases beginning in the Late Archaic period and extending through the Diversification period should be found in artifact assemblages from past projects. This is particularly true of excavated assemblages that represent individual components, which can be compared and contrasted with one another. Zier and Kalasz (1991) stated a quarter-century ago that little change was evident in terms of material culture and subsistence-related remains between the Late Archaic period and the Developmental period (then known as the Woodland or Early Ceramic period), stressing cultural continuity and not change. This notion should be reexamined in the light of newer evidence. Similarly, comparing and contrasting assemblages of Developmental and Diversification period age could shed light on functional and economic changes that occurred over the course of the Late Prehistoric stage. 
Acknowledgments. Thanks go to Mark Mitchell of Paleocultural Research Group for encouraging and supporting this effort, and for providing thoughtful review comments; Steven Mark Owens of Stell Environmental at Fort Carson Military Reservation, for providing archaeological data from Fort Carson and Pinon Canyon Maneuver Site; A. Dudley Gardner, formerly of Western Wyoming Community College, for providing numerous reports and papers of that institution's work in Picketwire Canyon and nearby areas; Travis R. Bugg, who drafted the regional map; Bob Cronk and Stephanie Boktor of the Office of Archaeology and Historic Preservation at History Colorado for furnishing reports and site data; Brooke Rohde of the University of Denver Museum of Anthropology for providing site information and reports related to E. B. Renaud's early work in southeastern Colorado; $\mathrm{H}$. Wolcott Toll III of the New Mexico Office of Archaeological Studies for attempting to track down information about an obscure Renaud site in northeastern New Mexico; and Kristin A. Gensmer and Christopher C. Kinneer of Centennial Archaeology, LLC, who allowed access to the company's library of technical reports and also provided office work space. Others who provided reports and/or specific site information include Cody M. Anderson of Metcalf Archaeological Consultants, Inc. and Jason LaBelle of the Department of Anthropology, Colorado State University. Special thanks to two anonymous reviewers whose detailed and thoughtful comments led to significant improvements in the manuscript.

\section{References Cited}

Adair, Mary J.

1988 Prehistoric Agriculture in the Central Plains. University of Kansas Publications in Anthropology 16. Department of Anthropology, University of Kansas, Lawrence.

Adams, Karen R.

1994 A Regional Synthesis of Zea mays in the Prehistoric American Southwest. In Corn and Culture in the Prehistoric New World, edited by Sissel Johannessen and Christine A. Hastoff, pp. 273-302. Westview Press, Boulder, Colorado.

Alexander, Robert K., John D. Hartley, and Thomas F. Babcock 1982 Settlement Survey of the Fort Carson Military Reservation. Grand River Consultants, Inc., Grand Junction, Colorado.

Anderson, Cody M.

2008 Excavations at the Gilligan's Island Shelters (5FN1592), Fort Carson Military Reservation (FCMR), Fremont County, Colorado. Unpublished Master's thesis, Department of Anthropology, Colorado State University, Fort Collins.

Anderson, Cody M., K. Talle Hogrefe, and Michael D. McFaul 2013 Mitigative Excavation of Five Archaeological Sites for the Raton 2010 Expansion Project in Southeastern Colorado. Prepared for El Paso Pipeline Partners, L.P. by Centennial Archaeology, Inc., Fort Collins, Colorado.

Andrefsky, William, Jr.

1990 Morphological Variability of Nonhafted Bifaces, Flake Tools, Cores, and Debitage from PCMS. In
An Introduction to the Archaeology of Pinon Canyon Southeastern Colorado, edited by William Andrefsky, Jr., pp. IX-145 - IX-231. Prepared for National Park Service - Rocky Mountain Regional Office by Larson-Tibesar Associates, Inc., Laramie, Wyoming and Centennial Archaeology, Inc., Fort Collins, Colorado.

Andrefsky, William, Jr., Marilyn J. Bender, John D. Benko, and Judy K. Michaelsen

1990 Test Excavations in the Pinon Canyon Maneuver Site, Southeastern Colorado. 2 volumes. Prepared for National Park Service - Rocky Mountain Regional Office by Larson-Tibesar Associates, Inc., Laramie, Wyoming.

Barker, Graeme

2006 The Agricultural Revolution in Prehistory: Why Did Foragers Become Farmers? Oxford University Press, Oxford.

Bellwood, Peter

2005 First Farmers: The Origins of Agricultural Societies. Blackwell Publishing, Oxford.

Berry, Michael S.

1985 The Age of Maize in the Greater Southwest: A Critical Review. In Prehistoric Food Production in North America, edited by Richard I. Ford. Anthropological Papers of the Museum of Anthropology 75. University of Michigan, Ann Arbor.

Binford, Lewis R.

1980 Willow Smoke and Dog's Tails: Hunter-Gatherer Settlement Systems and Archaeological Site Formation. American Antiquity 45(1):4-20.

Blake, Michael

2006 Dating the Initial Spread of Zea mays. In Histories of Maize: Multidisciplinary Approaches to the Prehistory, Linguistics, Biogeography, Domestication, and Evolution of Maize, edited by John E. Staller, Robert H. Tykot, and Bruce F. Benz, pp 55-72. Elsevier, Amsterdam.

Burrillo, R. E.

2016 Beans, Baskets, and Basketmakers: Testing the Assumption that Ceramics Were Necessary for the Adoption of Bean Cultivation on the Prehistoric Colorado Plateau. Southwestern Lore 82(2):35-49.

Campbell, Robert G.

1969 Prehistoric Panhandle Culture on the Chaquaqua Plateau, Southeast Colorado. Unpublished Ph.D. dissertation, Department of Anthropology, University of Colorado, Boulder.

Charles, Mona, Thann Baker, Christine Markussen, Randy Nathan, and Philip Duke

2005 Evaluative Testing of 5LA3421: A Multicomponent Prehistoric and Historic Site, Pinon Canyon Maneuver Site, Las Animas County, Colorado. Fort Carson Cultural Resource Management Series Contribution 14. Prepared for U.S. Army, Fort Carson Directorate of Environmental Compliance and Management by Fort Lewis College, Durango, Colorado.

Charles, Mona, Philip Duke, Randy Nathan, Sujan Bryan, and Christie Markussen

2000 ACultural Resource Inventory of High-and MediumSite Sensitivity Areas, Fort Carson Military Reservation: Fremont and Pueblo Counties, 1998. Fort Carson Cultural Resource Management Series Contribution 3. Prepared 
for U.S. Army, Fort Carson Directorate of Environmental Compliance and Management by Fort Lewis College, Durango, Colorado.

Chase, Haldon

1950 Journal of the Trinidad State Junior College High Plain Expedition. On file, Louden-Henritze Archaeology Museum, Trinidad State Junior College, Trinidad, Colorado.

Cummings, Linda Scott

2002 Pollen Analysis of Three Manos Recovered from a Human Burial, 5LA5838. Paleo Research Institute Technical Report 02-98. Prepared for Western Wyoming Community College by Paleo Research Institute, Golden, Colorado.

2005 Pollen Analysis of Samples from Sites 5EP46; Fort Carson Military Reservation and 5LA10370; Pinon Canyon Maneuver Site, Colorado. Paleo Research Institute Technical Report 05-38. Prepared for U.S. Army, Fort Carson Directorate of Environmental Compliance and Management, by Paleo Research Institute, Golden, Colorado.

Cummings, Linda Scott, R. A. Varney, and Kathryn Puseman 2004 Pollen Analysis of Three Manos Recovered in a Structure, and Pollen and Macrofloral Analysis of Fill from a Hearth, at the Picketwire Site, 5LA5838, Southeastern Colorado. Paleo Research Institute Technical Report 0339. Prepared for Western Wyoming Community College by Paleo Research Institute, Golden, Colorado.

Diamond, Jared

1987 The Worst Mistake in the History of the Human Race. Discover Magazine, May 1987.

Dick, Herbert W.

1956 Letter to "Trinchera Gang," dated February 28, 1956. On file, Louden-Henritze Archaeology Museum, Trinidad State Junior College, Trinidad, Colorado.

1965 Bat Cave. School of American Research Monograph 27. Santa Fe, New Mexico.

Doolittle, William E., and Jonathan B. Mabry

2006 Environmental Mosaics, Agricultural Diversity, and the Evolutionary Adoption of Maize in the American Southwest. In Histories of Maize: Multidisciplinary Approaches to the Prehistory, Linguistics, Biogeography, Domestication, and Evolution of Maize, edited by John E. Staller, Robert H. Tykot, and Bruce F. Benz, pp 109-121. Elsevier, Amsterdam.

Dumond, Don E.

1974 Population Growth and Political Centralization. In Population Growth: Anthropological Implications, edited by Brian Spooner, pp. 286-310. MIT Press, Cambridge, Massachusetts.

Fish, Suzanne K.

2004 Corn, Crops, and Cultivation in the North American Southwest. In People and Plants in Ancient Western North America, edited by Paul E. Minnis, pp. 115-166. Smithsonian Books, Washington, D.C.

Gardner, A. Dudley, Glade Hadden, Laura Pasacreta, and Emily Wollman

2010 The Apishapa and the Use of Cheno-ams and Maize: The Results of Excavations along the Purgatoire River, in Southeastern Colorado. Paper presented at the
Annual Meeting of the Colorado Council of Professional Archaeologists, Montrose, Colorado.

Gardner, A. Dudley, and Martin Lammers

2015a Report of Test Excavations at 5LA5840. Prepared for USDA Forest Service by Western Anthropological and Archaeological Research Institute, Rock Springs, Wyoming.

2015b Reportfor 2004 Test Excavations at 5LA6493: Major Revision (Revision of Western Wyoming Community College 2004, 2005 Report). Prepared for USDA Forest Service by Western Anthropological and Archaeological Research Institute, Rock Springs, Wyoming.

Gardner, A. Dudley, and Laura Pasacreta

2002 Preliminary Results of Test Excavations of Circular Structures on the Purgatory River. Prepared for USDA Forest Service by Western Wyoming College, Rock Springs.

Gardner, A. Dudley, Michelle Stevens, Laura Pasacreta, and Glade Hadden

2005 The Apishapa and the Use of Cheno-ams and Maize: The Results of Excavations along the Purgatory River, in Picketwire Canyon Colorado. Paper presented at the 63rd Annual Plains Anthropological Conference, Edmonton, Alberta.

Gilmore, Kevin P.

2008 The Context of Culture Change: Environment, Population, and Prehistory in Eastern Colorado, 1000 B.C. - A.D. 1540. Unpublished Ph.D dissertation, Division of Natural Sciences and Mathematics, University of Denver, Denver, Colorado.

Gunnerson, James H.

1989 Apishapa Canyon Archeology: Excavations at the Cramer, Snake Blakeslee and Nearby Sites. Reprints in Anthropology 41. J \& L Reprint Company, Lincoln, Nebraska.

Habu, Junko, and Ben Fitzhugh

2002 Introduction. In Beyond Foraging and Collecting: Evolutionary Change in Hunter-Gatherer Settlement Systems, edited by Junko Habu and Ben Fitzhugh, pp. 1-11. Kluwer Academic/Plenum Publishers, New York.

Hassan, Fekri A.

1981 Demographic Archaeology. Academic Press, New York.

Hayden, Brian D.

1992 Models of Domestication. In Transitions to Agriculture in Prehistory, edited by Anne Birgette Gebauer and T. Douglas Price, pp. 273-299. Monographs in World Archaeology 4. Prehistory Press, Madison, Wisconsin.

Huckell, Lisa W.

2006 Ancient Maize in the American Southwest: What Does It Look Like and What Can It Tell Us. In Histories of Maize: Multidisciplinary Approaches to the Prehistory, Linguistics, Biogeography, Domestication, and Evolution of Maize, edited by John E. Staller, Robert H. Tykot, and Bruce F. Benz, pp 97-107. Elsevier, Amsterdam.

Huckell, Lisa W., and Mollie S. Toll

2004 Wild Plant Use in the Northern American Southwest. In People and Plants in Ancient Western North America, edited by Paul E. Minnis, pp. 37-114. 
Smithsonian Books, Washington, D.C.

Ireland, Stephen K.

1968 Five Apishapa Focus Sites in the Arkansas Valley,

Colorado. Unpublished Master's thesis, Department of

Anthropology, University of Denver, Denver, Colorado.

Kalasz, Stephen M.

1988 Temporal and Spatial Distribution of Prehistoric

Architecture in the Taylor Arroyo Drainage Basin of

Southeastern Colorado. Unpublished Master's thesis,

Department of Anthropology, Northern Arizona University, Flagstaff.

1990 Prehistoric Feature Analysis. In An Introduction to the Archaeology of Pinon Canyon, Southeastern Colorado, Volume II, edited by William Andrefsky, Jr., pp. XII1-XII-90. Prepared for National Park Service, Rocky Mountain Regional Office by Larson-Tibesar Associates, Inc., Laramie, Wyoming and Centennial Archaeology, Inc., Fort Collins, Colorado.

Kalasz, Stephen M., Cody M. Anderson, Bonnie K. Gibson, John D. Kennedy, Christopher C. Kinneer, Lawrence L. Loendorf, and Cortney A. Wands

2007 Archaeological Investigations at Sites 5LA3186, 5LA3188, and 5LA3189 along Burke Arroyo in the Pinon Canyon Maneuver Site, Las Animas County, Colorado. Prepared for New Mexico State University and the U.S. Army by Centennial Archaeology, Inc., Fort Collins, Colorado.

Kalasz, Stephen M., Daniel A. Jepson, Christian J. Zier, and Margaret A. Van Ness

1993 Test Excavation of Seven Prehistoric Sites on the Fort Carson Military Reservation, El Paso and Pueblo Counties, Colorado. Prepared for the U.S. Army and the National Park Service by Centennial Archaeology, Inc., Fort Collins, Colorado.

Kalasz, Stephen M., Christian J. Zier, and Mark Mitchell

1999 Theoretical Considerations and Cultural

Systematics. In Colorado Prehistory: A Context for the

Arkansas River Basin, by Christian J. Zier and Stephen

M. Kalasz, pp. 43-72. Colorado Council of Professional

Archaeologists, Denver.

Keeley, Lawrence H.

1995 Proto-agricultural Practices among HunterGatherers. In Last Hunters, First Farmers: New Perspectives on the Prehistoric Transition to Agriculture, edited by T. Douglas Price and Anne Birgette Gebauer, pp. 243-272. School of American Research Press, Santa Fe, New Mexico.

Kingsbury, Lawrence A., and Michael Nowak 1980 Archaeological Investigations on Carrizo Ranches, Inc., 1974-1979. Publications in Archaeology

2. Department of Anthropology, Colorado College, Colorado Springs.

Krishna, K. R.

2013 Maize Agroecosystem: Nutrient Dynamics and Productivity. Apple Academic Press, Point Pleasant, New Jersey.

Lee, Richard B.

1976 !Kung Spatial Organization: An Ecological and Historical Perspective. In Kalahari Hunter-Gatherers: Studies of the !Kung San and Their Neighbors, edited by
Richard B. Lee and Irven DeVore, pp. 71-97. Harvard University Press, Cambridge, Massachusetts.

Lintz, Christopher Ray

1984 Architecture and Community Variability within the Antelope Creek Phase of the Texas Panhandle. Unpublished Ph.D. dissertation, Graduate College, University of Oklahoma, Norman.

Lintz, Christopher, and Leon George Zabawa

1984 The Kenton Caves of Western Oklahoma. In Prehistory of Oklahoma, edited by Robert E. Bell, pp. 161174. Academic Press, New York.

Mangelsdorf, Paul C., Herbert W. Dick, and Julián CámaraHernández

1967 Bat Cave Revisited. Harvard University Botanical Museum Leaflets 22(1):1-29.

Matthews, Meredith

2001 Appendix VI: Results of Analysis of Macrobotanical Remains from Four Sites in the Fort Carson Military Reservation, Colorado. In Evaluative Testing of 13 Sites on the Fort Carson Military Reservation, El Paso and Pueblo Counties, Colorado, by Mona Charles, Philip Duke, Randy Nathan, and Christie Markussen, pp. VI.1-VI.12. Fort Carson Cultural Resource Management Series Contribution 6. Prepared for U.S. Army, Fort Carson Directorate of Environmental Compliance and Management by Fort Lewis College, Durango, Colorado. Minnis, Paul E.

1981 Economic and Organizational Responses to Food Stress by Non-Stratified Societies: An Example from Prehistoric New Mexico. Unpublished Ph.D. dissertation, Department of Anthropology, University of Michigan, Ann Arbor.

1985 Domesticating People and Plants in the Greater Southwest. In Prehistoric Food Production in North America, edited by Richard I. Ford, pp. 309-339. Anthropological Papers of the Museum of Anthropology 75. University of Michigan, Ann Arbor.

1992 Earliest Plant Cultivation in the Desert Borderlands of North America. In The Origins of Agriculture: An International Perspective, edited by C. Wesley Cowan and Patty Jo Watson, pp. 121-141. Smithsonian Institution Press, Washington, D.C.

Mutel, Cornelia Fleischer, and John C. Emerick

1984 From Grassland to Glacier: The Natural History of Colorado and the Surrounding Region. Johnson Printing, Boulder, Colorado.

Neumann, Katharina

2005 The Romance of Farming: Plant Cultivation and Domestication in Africa. In African Archaeology: A Critical Introduction, edited by Ann Brower Stahl, pp. 249-275. Blackwell Studies in Global Archaeology. Blackwell Publishing Ltd., Malden, Massachusetts.

Nowak, Michael, and Andrew Fahlund

1994 Archaeological Investigations in Southeastern Colorado: The Archaeology of the Snakeweb Site, 5LA5855 and Reconnaissance Efforts in Northeastern Pintada Canyon. Publications in Archaeology 18. Department of Anthropology, Colorado College, Colorado Springs.

Nowak, Michael, and Christopher A. Jones

1986 Archaeological Investigations in Southeastern 
Colorado. Publications in Archaeology 9. Department of Anthropology, Colorado College, Colorado Springs.

Nowak, Michael, and John W. Kantner

1991 Archaeological Investigations in Southeastern Colorado. Publications in Archaeology 16. Department of Anthropology, Colorado College, Colorado Springs.

Nowak, Michael, and Ethan Morton

1998 Archaeological Investigations in Southeastern Colorado. Publications in Archaeology 19. Department of Anthropology, Colorado College, Colorado Springs.

Nowak, Michael, and Kimberly Spurr

1989 Archaeological Investigations in Southeastern Colorado: 1988 Field Season. Publications in Archaeology 14. Department of Anthropology, Colorado College, Colorado Springs.

Painter, Mary W., Amy Holmes, Michael McFaul, and Christian J. Zier

1999 Environmental Setting. In Colorado Prehistory: A Context for the Arkansas River Basin, by Christian J. Zier and Stephen M. Kalasz, pp. 5-24. Colorado Council of Professional Archaeologists, Denver.

Perreault, Charles, and P. Jeffrey Brantingham

2010 Mobility-Driven Cultural Transmission along the Forager-Collector Continuum. Journal of Anthropological Archaeology 30(2011):62-68.

Plog, Fred T.

1974 The Study of Prehistoric Change. Academic Press, New York.

Price, T. Douglas, and Anne Birgette Gebauer

1995 Preface. In Last Hunters, First Farmers: New Perspectives on the Prehistoric Transition to Agriculture, edited by T. Douglas Price and Anne Birgette Gebauer, pp. xiii. School of American Research Press, Santa Fe, New Mexico.

Price, T. Douglas, Anne Birgette Gebauer, and Lawrence H. Keeley

1995 The Spread of Farming into Europe North of the Alps. In Last Hunters, First Farmers: New Perspectives on the Prehistoric Transition to Agriculture, edited by T. Douglas Price and Anne Birgette Gebauer, pp. 95-126. School of American Research Press, Santa Fe, New Mexico.

Puseman, Kathryn

2013 Macrofloral Analysis of Fill from a Hearth-like Feature in a Circular Stone Structure at the Wooten 2 Site, 5LA11248, Southeast Colorado. Technical Report 13004. Prepared for Western Wyoming Community College by Paleoscapes Archaeobotanical Research Team (PAST), LLC, Bailey, Colorado.

Puseman, Kathryn, and Linda Scott Cummings

2006 Pollen and Macrofloral Analysis of Site 5LA6493, Comanche National Grasslands, Colorado. Paleo Research Institute Technical Report 05-02. Prepared for Western Wyoming Community College by Paleo Research Institute, Golden, Colorado.

2007 Pollen, Starch, Macrofloral, and Protein Residue Analysis at Site 5LA5840, Southeast Colorado. Paleo Research Institute Technical Report 01-56/07-14. Prepared for Western Wyoming Community College by Paleo Research Institute, Golden, Colorado.
Renaud, Etienne B.

1930 A Summary of Prehistoric Cultures in the Cimarron Valley. El Palacio 29:123-129.

1933 Archaeological Survey of Eastern Colorado, Third Report. University of Denver, Denver, Colorado.

1937 Archaeological Survey of the High Western Plains, Ninth Report: Northeastern New Mexico. University of Denver, Denver, Colorado.

1947 Archaeology of the High Western Plains: Seventeen Years of Archaeological Research. Department of Anthropology, University of Denver, Denver, Colorado.

Rexroth, Allison

2010 Prehistoric Sandals of the Southern High Plains: Indicators of Cultural Affinity and Change. Unpublished Master's thesis, Department of Anthropology, University of Denver, Denver, Colorado.

Rhodes, Diane Lee

1984 Upper Plum Canyon Rock Shelter I: Las Animas County, Colorado. Unpublished Master's thesis, Department of Anthropology, University of Colorado, Boulder.

Roper, Donna C

2007 The Origins and Expansion of the Central Plains Tradition. In Plains Village Archaeology: Bison-hunting Farmers in the Central and Northern Plains, edited by Stanley A. Ahler and Marvin Kay, pp. 53-63. University of Utah Press, Salt Lake City.

Sanders, Paul H.

1990 Ceramic Analysis. In An Introduction to the Archaeology of Pinon Canyon Southeastern Colorado, edited by William Andrefsky, Jr., pp. IX-145 - IX-231. Prepared for National Park Service, Rocky Mountain Regional Office by Larson-Tibesar Associates, Inc., Laramie, Wyoming, and Centennial Archaeology, Inc., Fort Collins, Colorado.

Schiavitti, Vincent W.

2003 Archaeological Investigations from 1998 at Six Sites on the Pinon Canyon Maneuver Site, Las Animas County, Colorado. Fort Carson Cultural Resource Management Series Contribution 12. Prepared for National Park Service, Midwest Archeological Center by New Mexico State University, Las Cruces.

Schuldenrein, Joseph (assembler)

1985 Geomorphological and Geoarchaeological Investigations at the U.S. Army Fort Carson-Pinon Canyon Maneuver Site, Las Animas County, Colorado. Prepared for National Park Service, Rocky Mountain Regional Office by Gilbert/Commonwealth, Inc., Jackson, Michigan.

Simpson, Caryl Wood

1976 Trinchera Cave: A Rock Shelter in Southeastern Colorado. Unpublished Master's thesis, Department of Anthropology, University of Wyoming, Laramie.

Thornbury, William D.

1965 Regional Geomorphology of the United States. John Wiley \& Sons, Inc., New York.

Toll, H. Wolcott, Mollie S. Toll, Marcia L. Newren, and William B. Gillespie

1985 Experimental Corn Plots in Chaco Canyon: The Life and Hard Times of Zea mays L. In Environment 
and Subsistence of Chaco Canyon, New Mexico, edited by F. Joan Mathien, pp. 79-133. Chaco Canyon Studies, Publications in Archaeology 18E. National Park Service, Albuquerque, New Mexico.

Toll, Mollie S.

1990 Botanical Remains. In Archaeological Survey and Test Excavation in the Turkey Canyon Area, Fort Carson Military Reservation, Pueblo and El Paso Counties, Colorado, by Margaret A. Van Ness, Stephen M. Kalasz, Christian J. Zier, Daniel A. Jepson, Mollie S. Toll, Richard F. Madole, and Richard F. Carrillo, pp. 274-277. Prepared for U.S. Army and National Park Service by Centennial Archaeology, Inc., Fort Collins, Colorado.

Van Ness, Margaret A.

1986 Flotation Analysis of Two Sites in Southeastern Colorado. In Archaeological Investigations in Southeastern Colorado, by Michael Nowak and Christopher A. Jones, pp. 95-109. Publications in Archaeology 9. Department of Anthropology, Colorado College, Colorado Springs.

1989 Macrobotanical Remains from Site 5LA2146 in Southeast Colorado, 1988 Field Season. In Archaeological Investigations in Southeastern Colorado: 1988 Field Season, by Michael Nowak and Kimberly Spurr, pp. 87-98. Publications in Archaeology 14. Department of Anthropology, Colorado College, Colorado Springs.

Van Ness, Margaret A., Stephen M. Kalasz, Christian J. Zier, Daniel A. Jepson, Mollie S. Toll, Richard F. Madole, and Richard F. Carrillo

1990 Archaeological Survey and Test Excavation in the Turkey Canyon Area, Fort Carson Military Reservation, Pueblo and El Paso Counties, Colorado. Prepared for U.S. Army and National Park Service by Centennial Archaeology, Inc., Fort Collins, Colorado.

Varney, R. A.

2004 Stratigraphic Pollen Analysis at 5LA5838, a Circular Structure in Picketwire Canyon, Southeastern Colorado. Paleo Research Institute Technical Report 0389. Prepared for Western Wyoming Community College by PaleoResearch Institute, Golden, Colorado.

Vernet, R.

2002 Climate during the Later Holocene in the Sahara and the Sahel: Evolution and Consequences on Human Settlement. In Droughts, Food and Culture: Ecological Change and Food Security in Africa's Later Prehistory, edited by Fekri A. Hassan, pp. 47-63. Kluwer Academic/ Plenum Publishers, New York.

Watts, Howard K.

1971 The Archaeology of the Avery Ranch Site on Turkey Creek, Southeastern Colorado. Unpublished Master's thesis, Department of Anthropology, University of Denver, Denver, Colorado.

1975 The Avery Ranch Site. Southwestern Lore 41(1):1527.

Wedel, Waldo R.

1986 Central Plains Prehistory: Holocene Environments and Culture Change in the Republican River Basin. University of Nebraska Press, Lincoln.

Western Regional Climate Center

2016 Colorado Climatic Summaries. Electronic resource, http://www.wrcc.dri.edu/summary/climsmco.

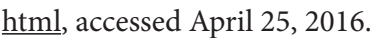

Wills, W. H.

1988 Early Prehistoric Agriculture in the American Southwest. School of American Research Press, Santa Fe, New Mexico.

1992 Foraging Systems and Plant Cultivation during the Emergence of Agricultural Economies in the Prehistoric American Southwest. In Transitions to Agriculture in Prehistory, edited by Anne Birgette Gebauer and T. Douglas Price, pp. 153-176. Monographs in World Archaeology 4. Prehistory Press, Madison, Wisconsin.

1995 Archaic Foraging and the Beginning of Food Production in the American Southwest. In Last Hunters, First Farmers: New Perspectives on the Prehistoric Transition to Agriculture, edited by T. Douglas Price and Anne Birgette Gebauer, pp. 215-242. School of American Research Press, Santa Fe, New Mexico.

Wilshusen, Richard H., and Elizabeth M. Perry

2012 Women's Central Role in Early Pueblo Change: Ground Stone, Archaeobotanical, Ceramic, Architectural, and Skeletal Evidence. In Crucible of Pueblos: The Early Pueblo Period in the Northern Southwest, edited by Rchard H. Wilshusen, Gregson Schachner, and James R. Allison, pp. 185-197. Cotsen Institute of Archaeology Press Monograph 17. University of California, Los Angeles.

Zabawa, Leon George

1981 The Kenton Caves Re-Examined. Electronic resource, http://kentoncaves.blogspot.com/2008/06/ blog-post.html, accessed August 1, 2015.

Zier, Christian J.

2015 Reconstructing Trinchera Cave: An Examination of the Excavation History, Chronology, and Stratigraphy of Site 5LA1057, Las Animas County, Colorado. Prepared for Kinder Morgan, Inc. and History Colorado, State Historical Fund by Centennial Archaeology, Inc., Fort Collins, Colorado.

Zier, Christian J. (editor)

1989 Archaeological Excavation of Recon John Shelter (5PE648) on the Fort Carson Military Reservation, Pueblo County, Colorado. Prepared for U.S. Army and National Park Service by Centennial Archaeology, Inc., Fort Collins, Colorado.

Zier, Christian J., and Stephen M. Kalasz

1991 Recon John Shelter and the Archaic-Woodland Transition in Southeastern Colorado. Plains Anthropologist 36(135):111-138.

1999 Colorado Prehistory: A Context for the Arkansas River Basin. Colorado Council of Professional Archaeologists, Denver.

Zier, Christian J., Stephen M. Kalasz, Anne H. Peebles, Margaret A. Van Ness, and Elaine Anderson

1988 Archaeological Excavation of the Avery Ranch Site (5PE56) on the Fort Carson Military Reservation, Pueblo County, Colorado. Prepared for U.S. Army and National Park Service by Centennial Archaeology, Inc., Fort Collins, Colorado.

1990 The Avery Ranch Site Revisited. Plains Anthropologist 35(128):147-173. 
Zubrow, Ezra B. W.

1972 Carrying Capacity and Dynamic Equilibrium in the Prehistoric Southwest. In Contemporary Archaeology: A Guide to Theory and Contributions, edited by Mark P. Leone, pp. 268-279. Southern Illinois University Press, Carbondale.

\section{Contributor Notes}

Christian J. Zier holds a Ph.D. in anthropology from the University of Colorado - Boulder and has worked as a professional archaeologist for nearly four decades. He owned and operated Centennial Archaeology, Inc., a cultural resource management firm, for 30 years (1984-2014). He has conducted archaeological field investigations in many parts of the western U.S. as well as Central America, Africa, and Asia. He is the current editor of Southwestern Lore, the journal of the Colorado Archaeological Society. 